\title{
African development and the marginalisation of domestic capitalists
}

Pritish Behuria $^{1}$

May 2019

1 Global Development Institute, The University of Manchester Email correspondence: pritish.behuria@manchester.ac.uk

ISBN: 978-1-912593-17-0 


\begin{abstract}
The revival of industrial policy discussions has operated in parallel to reports of increasing domestic wealth accumulation across the African continent. Regional and continent-wide industrialisation has begun to be rhetorically linked to discussions of regional common markets and through the African Continental Free Trade Area. Yet, there is barely any mention of integrating African capital into the African industrial policy agenda. Where such discussions have appeared, they have emerged through the 'Africapitalism' narrative, which ignores the role of the state and politics in supporting and sustaining domestic business groups. Instead, the re-imagination of industrial policy on the continent relies on foreign investors, particularly the relocation of Chinese industry to various parts of the continent.
\end{abstract}

This paper has two core objectives. The first is to explain why the study of African capitalists - popular in the 1980s and 1990s - has remained relatively dormant since then. Dominant narratives - through neopatrimonalism and dependency-inspired arguments - have been pessimistic about the potential of African capitalists to deliver structural transformation. Gradually, these narratives, alongside intellectual trends within mainstream social science and African studies, have discouraged the study of politics of state-business relations in Africa. Yet African capitalists have become increasingly prominent in popular culture. Many of the wealthiest and most prominent capitalists have emerged through owning diversified business groups across the continent. This paper argues that more attention should be dedicated to the study of the politics of the emergence and sustenance of African diversified business groups (DBGs). To achieve this goal, a fluid categorisation of DBGs is introduced, building on Ben Ross Schneider's previous work. By examining three country case studies Rwanda, Kenya and Tanzania - this paper highlights how a range of DBGs are emerging across three very different political contexts.

Keywords: State-business relations, diversified business group, Africa, Rwanda, Kenya, Tanzania, capitalism, business, capitalist

Acknowledgements: This paper is part of ongoing research, for an ESID project on Diversified Business Groups in Africa, led by the author. Benjamin Chemouni, Michaela Collord, Laura Mann, Anne Pitcher, Nicolai Schulz, Lindsay Whitfield, Alexandra Zeitz and ESID reviewers have provided thoughtful comments that have improved this paper. Thanks to them for reading different versions of this paper over the last year. An early version of this paper was presented at a workshop on the Politics of Economic Policy in African Countries, at the Oxford Martin School in January 2019. Thank you to those who attended for their very useful feedback. Any errors and omissions are my sole responsibility. 
Behuria, P. (2019) African development and the marginalisation of domestic capitalists. ESID Working Paper No. 115. Manchester, UK: The University of Manchester. Available at www.effective-states.org

This document is an output from a project funded by UK Aid from the UK government for the benefit of developing countries. However, the views expressed and information contained in it are not necessarily those of, or endorsed by the UK government, which can accept no responsibility for such views or information or for any reliance placed on them. 


\subsection{Introduction}

What is certain is that, as a result partly of prejudice and partly of socialist dogma, Africa's capitalists have not yet been taken seriously enough. ${ }^{1}$

African capitalists and their contribution to processes of capitalist transformation have remained marginal to the study of African politics and development. John lliffe's quote (above), also highlighted in the introduction of Berman and Leys' (1994) seminal edited collection, African Capitalists in African Development, remains as pertinent today as it was more than three decades ago. Iliffe's observations about African capitalists, made in the 1980s, were followed by several attempts to examine the status of domestic capitalists in African countries, with some (Lubeck, 1987) identifying the existence of productive bourgeoisies in some countries. Yet the mainstream thrust of neoclassical, public choice and neopatrimonialism-based explanations of African development, as well as the pessimistic arguments of dependency theorists, contributed to a pessimistic consensus with regard to the position of domestic capitalists within capitalist transformation processes in their countries. The new consensus argued that African capitalists were either unproductive or did not have the same potential to contribute to productive transformation as in countries like the East Asian developmental states (Amsden, 1989; Wade, 1990; Evans, 1995).

The recent increased popularity of industrial policy discussions among African governments, and within academic scholarship, should present an opening to refocus our attention on the status of domestic capitalists within African countries. In 2018, African leaders signed a framework, establishing the African Continental Free Trade Area (AfCFTA). The proposed AfCFTA will work alongside existing regional trade agreements across the continent, with the leaders of African governments committing to work together to develop a continent-wide industrial policy that contributes to the structural transformation of all African countries. Though ambitious, hopeful and far from being realised, the attempt to link industrialisation directly with regional trade harks back to similar objectives of industrial coordination across the continent, proposed by the United Nations Economic Commission for Africa in the 1960s (UN, 1964 Ewing, 1964). ${ }^{2}$

These proposals have coincided with Africa's richest businesspeople achieving global prominence. Within the continent, their voices are influential - both because of the number of people they employ and because of the political influence that accompanies their wealth. African businesspeople enjoy both 'structural power' and 'instrumental power', but the ways in which this power has been exercised to support their emergence has been understudied. ${ }^{3}$ Forbes reports that there are 23 African

\footnotetext{
1 lliffe $(1983,87)$.

2 UNECA's arguments were inspired by Raul Prebisch's (1959) proposals for regional industrialisation to combat the unfair biases within the international trade system.

${ }^{3}$ Businesses have structural power because the national economy depends on their investments to sustain the economy and provide employment and tax revenues. Thus, governments respond to the structural power of businesses because of an 'investment
} 
billionaires in 2018 (and this number has been rising over the years). The list is led by South Africa (eight), followed by Egypt (six), Nigeria (three), Morocco (two), Tanzania (one), Zimbabwe (one), Angola (one) and Algeria (one). ${ }^{4}$ Acknowledging the increasing wealth on the continent, Nigerian businessman Tony Elumelu coined the term 'Africapitalism' to denote an economic philosophy that has gathered pace among African businesspeople, which aims to combine profit motives with the political and economic ideas of African unity (Iheduru, 2018).

Yet Africapitalism - both in the narratives through which it has been presented and in its proposed practice - is restrictively imagined within the realms of a market-led economy where the state's actions remain marginal. ${ }^{5}$ While governments have tended to ignore domestic capitalists in promoting industrialisation, Africapitalism has ignored the role that governments have played in enabling the growth of wealth of Africa's richest businesspeople, suggesting increased difficulties with engaging in public rhetoric that highlights the importance of close state-business relationships. Though management and business studies scholars have begun to study Africapitalism (Amaeshi and Idemudia, 2015), an examination of politics and state support is missing from their analyses. The Pan-Africanist symbolism of 'Africapitalism' combines with market-led notions of entrepreneurship to liken the success of African businesspeople to the success of similar 'self-made' stories elsewhere in the world. Both within Africa and the West, narratives have developed that wipe out the role of the state and the political nature of economic success. Emulators seeking to follow the story of successful businesspeople are sold an aspirational story that erases political details and obscures the political economy realities of successful business empires.

Even within recently revived studies of industrial policy - through new structural economics (NSE) (Lin, 2012) - there is limited space for domestic capitalists to be selected as key capitalist partners. NSE does not focus on the importance of securing domestic markets, as more heterodox forms of industrial policy did (Amsden, 2007). NSE's overwhelming focus on export-orientation has tended to ignore the importance of supporting the growth of domestic firms, which have grown through domestic markets. NSE has tended to ignore import substitution industrialisation (ISI), which was a key source of growth for many diversified business groups (DBGs) in developing countries (including the chaebol in Korea). Where domestic firms are discussed within NSE, their potential is perceived to be restricted through their potential to link to established global value chains/global production

imperative' (Lindblom, 1977; Block, 1987), where business investments are required to fund the country's economic activity to help keep ruling politicians in power. Instrumental power comprises the ways in which businesses influence politics (outside the core functions of firms): campaign donations, membership associations, lobbying activities and privileged access to policymakers (Culpepper, 2011).

${ }^{4}$ However, such lists underestimate the wealth of certain prominent business families and politicians, given the extent of capital flight in the continent (Boyce and Ndikumana, 2001) and since Forbes' methodologies have several limitations, including excluding diversified family businesses, such as Manu Chandaria's family in Kenya and the Madhvanis in Uganda.

${ }^{5}$ See Ouma (2019) for a critique of 'Africapitalism'. 
networks (GVCs/GPNs). African countries have tended to embrace NSE (at least in their policy documents), failing to prioritise domestic firms producing for domestic and regional markets. Instead, for African countries, attracting relocated Chinese industries is the most popular route to achieving successful industrial policy (Lin, 2018). This is most notable in Ethiopia, where Chinese investment has become central to the growth of the manufacturing industry, with government officials admitting difficulties in supporting the growth of domestic investors (Oqubay, 2015). Foreign investors will always be important, given their comparative advances in technological acquisition (Lall, 2005) and their advanced positions in GVCs/GPNs. Yet there are few cases where foreign investment has been leveraged to support the emergence of domestic capitalist classes or business groups.

The limited attention paid to African capitalists within academic scholarship is striking. Yet, since independence, African firms of various types - state-owned firms, party-owned or military-owned firms, investment groups, family businesses and other diversified business groups (DBGs) - have emerged as leading actors within the development strategies of their countries. This paper questions why literature on African development continues to ignore the status and evolution of domestic capitalists. It argues that pessimism about the 'comprador' and 'rent-seeking' nature of African capitalists has discouraged the study of African capitalists. The intent of conducting such research has been eclipsed by growing intellectual trends (including the export-oriented discussions of GVC/GPN studies and neoliberalism-influenced discussions on empowering business environments, small enterprises and entrepreneurship). Both the African studies and the broader mainstream social science scholarship has been largely influenced by the neoclassical, public choice and neopatrimonialism-based arguments commonly used to characterise African politics and development. In the next two sections, the paper discusses the evolution of debates about African capitalists and their potential to support catch-up development in their countries and details the state of research on the study of African capitalists and firms.

The paper then proposes a new, preliminary approach to studying the politics of state-business relationships in Africa through a focus on studying the evolution of African DBGs. Context-specific historical political economy methods are used to evaluate how politics has shaped the emergence of a variety of African firms. DBGs form a focus of this analysis, primarily because they maintain diversified cross-sector interests that mean their economic activities are much more closely aligned with growth in their host economies, rather than narrow sectoral interests. DBGs are chosen as the subject of the study, as they are the largest private domestic capitalist organisations in most developing countries and require further study. To underscore the importance of politics, a fluid categorisation of African DBGs is developed, based on Schneider (2009). The following section then discusses the evolving political economy of four countries - Rwanda, Kenya and Tanzania - to showcase how politics has shaped the emergence of a variety of African DBGs. The last section ends on a hopeful note, arguing that defeating intellectual pessimism with regard to the potential of productive state-business relations can create space for discussions 
on how to integrate domestic capital into the revived industrialisation strategies across the African continent.

This paper is based on fieldwork conducted by the author in Rwanda, Kenya, Tanzania, Uganda, Ethiopia and Mauritius. Discussions of specific cases are brief and do not do justice to the histories of specific businesses and the evolution of state-business relationships. The Kenya and Tanzania cases will be elaborated in future working papers and the Rwanda case has been discussed elsewhere (Booth and Golooba-Mutebi, 2012; Gokgur, 2012; Behuria, 2015, 2016, 2018a). The paper's intention is to begin engagement with existing literature - like Schneider's (2009) - in the broader politics of state-business relations literature, to help illuminate how politics in specific countries has shaped the growth trajectories of DBGs. In doing so, the paper (and future work) highlights how African DBGs have differed among themselves and in relation to DBGs elsewhere.

\subsection{African studies and the case of the missing domestic capitalists}

In the post-war years, questioning whether emerging capitalist classes in African countries could propel their countries through processes of transformation fascinated segments of African studies scholarship. Initially, a pessimistic tone reigned, with arguments that domestic ruling elites and domestic capital (where it had emerged) would only act as 'compradors', pursuing the interests of foreign capital. But by the late 1970s and 1980s, some scholars (Kennedy, 1977; Lubeck, 1987) were taking a more optimistic tone, arguing that emerging capitalist classes showed potential to lead a national development project.

The divide between the pessimism of dependency scholarship and the optimism of more hopeful scholars was made most clear in literature that came to be known as the 'Kenya debate'. In the 1970s, Colin Leys (1975) was among a group of scholars studying Kenyan development, and initially argued that he saw no signs of an emerging Kenyan bourgeoisie that could challenge the dominant position of foreign capital. Later, he (1978) changed his mind, after being convinced by Nicola Swainson's (1980) findings that through the Kenyan government's support, a national bourgeoisie had begun to emerge. Yet scholarship (Langdon, 1977; Kaplinsky, 1980), working within the dependency tradition, retained its doubts about the potential of Kenyan capitalist classes. Evidence used by both sides of the debate remained ambiguous (Kitching, 1985) and no clear winner emerged. ${ }^{6}$

Though the debate on Kenya's capitalists did not reach a decisive conclusion, pessimism regarding the prospects of domestic capitalists driving a national development project persisted. Several explanations were provided to support this pessimistic stance. First, in the 1990s, there was a consensus that African capitalist classes had not emerged, with one scholar (Leys, 1994, 12) reasoning that the formation of a capitalist class was never 'the work of a generation or two' and

\footnotetext{
${ }^{6}$ Boone (1992) highlights a similar debate emerging in the Nigeria literature at the same time (lliffe, 1983; Biersteker, 1987; Forrest, 1987).
} 
required a much longer time span. Second, scholars argued that a 'bureaucratic bourgeoisie' had emerged, with state officials using their positions in power to acquire control over productive assets and constraining the growth of private capitalists (Shivji, 1976). In some cases, 'surpluses flowed from peasants to bureaucrats' (Kasfir, 1987, 50), with a new 'political class' emerging through bureaucratic control. In some African countries (like Kenya), this 'bureaucratic bourgeoisie' eventually left the public sector entirely and, in some countries, they are among the largest owners of DBGs. In effect, the 'bureaucratic bourgeoisie' has gradually contributed to creating capitalists in some countries.

Third, post-independence governments were perceived to be reluctant to support domestic businessmen because they feared such individuals would develop alternative sources of power, which could threaten political stability (Tangri, 1998; Mkandawire and Soludo, 1999). ${ }^{7}$ Fear of empowering capitalists has characterised state-business relations globally. Even among Northeast Asian developmental states (Korea and Taiwan) - where governments experienced the external threat of communism - there were different responses to organising state-business relations. In Korea, Park-Chung Hee decided that the most appropriate response was to work closely with the private sector to encourage the creation, concentration and diversification of the activities of DBGs (Korea's chaebol) (Kim, 1997). In comparison, the ruling Kuomintang government had concerns about business influence and that motivated them to control the financial sector and keep private firms small (Cheng, 1993). Thus, even where there were similar internal and external threats (Doner et al., 2005), the ways in which capital was organised differed significantly (privatelyowned DBGs in Korea versus state-run enterprises in Taiwan), but resulted in similarly productive outcomes.

Fourth, Boone (1994) drew attention to the negative effects of a legacy of decolonisation where ruling groups were out of touch with agrarian classes. Thus, existing domestic agrarian capital was ignored, as post-independent governments embarked on their pursuit of national development projects. As politically mediated access to state resources became an important avenue for domestic accumulation, rentierism in the commercial sector - particularly in trading - inhibited the expansion of capital (Boone, 1990). Thus, the composition of post-independence economies had changed, where the government's political logic did not motivate officials to support the expansion of capital in productive enterprises.

Fifth, the influence of assumptions associated with 'neopatrimonialism' - seen as 'the distinctive institutional hallmark of African regimes' (Bratton and Van de Walle, 1994, 458) - has played a considerable role in casting doubts about the potential of emergence of productive capitalists (working closely with African governments). ${ }^{8}$

\footnotetext{
${ }^{7}$ Recent work on business financing of opposition election campaigns in Africa explores this in detail (Arriola, 2013).

${ }^{8}$ Neopatrimonialism is defined as 'a form of organization in which relationships of a broadly patrimonial type pervade a political and administrative system, which is formally constructed on rational-legal lines. Officials hold positions in bureaucratic organizations with powers,
} 
'Neopatrimonialism' was initially employed to characterise traditional Weberian forms of patrimonialism and rational-legal authority in modern contexts (Eisenstadt, 1966). Aristide Zolberg (1966) first applied the term to characterise the traditional patterns of authority exhibited by West African parties. ${ }^{9}$ While initial work used the term to highlight that neopatrimonialism was a consequence of the influence of premodern cultural norms or an effect of colonialism, by the 1980s, 'neopatrimonalism' was primarily used to explain poor economic performances in African countries (Pitcher et al., 2009). Taylor (2012) criticises the argument that there is a single 'African neopatrimonial' culture, given the diversity of groups that live across the continent, and also stresses that commercial enterprise in Africa prior to colonialism was not just pervasive, but prolific. ${ }^{10}$ The argument that foreign cultures are a hindrance to the development of foreign countries has been popular in Western scholarship for generations. Weber, himself, was of the opinion that China's economic backwardness was fostered by Confucian values (McVey, 1992). Recent evidence of China's development successes showcases the problems that Weber's assumptions held, and the diversity of historical experiences across the African continent should discount any neopatrimonialism-based explanations of African development.

Proponents of neopatrimonialism-based explanations of African development have argued that it has obstructed the emergence of capitalist classes in African countries (Sandbrook, 1986). Neopatrimonialism-based explanations closely tallied with the arguments of the World Bank and neoclassical economists, who argued for the enactment of structural adjustment reforms in the 1980s and 1990s, reasoning that the limited development in African countries was largely because of the corruption that had characterised state-business relations across the continent. Yet others (Pitcher et al., 2009), using the case of Botswana, argue that there is no reason neopatrimonialism and development cannot co-exist. Recent scholarship has used the concept of 'developmental patrimonialism' to hold that rents derived through clientelism can be used for productive purposes (Booth and Golooba-Mutebi, 2012; Kelsall, 2013). However, scholarship working within the confines of neopatrimonialism-based assumptions assumes a 'modal pattern' of rent-seeking in relation to African development, failing to account for the diversity of experiences across African countries (Mkandawire, 2015; Behuria et al., 2017).

\subsection{Intellectual trends}

Neopatrimonialism and Afro-pessimism have influenced the literature on African studies to the extent that scholarship tends to assume that there are few examples of productive African capitalists (and capitalist classes) across the continent (Handley, 2008). However, an even stronger influence has been changing global intellectual trends that have contributed to marginalising the study of African capitalists. The dominance of mainstream discourse, emphasising the positives of market-led reforms, has led to a growing focus on entrepreneurship, both in academic and policy

which are formally defined, but exercise those powers ... as a form of private property' (Clapham, 1985, 48).

${ }^{9}$ See Mkandawire (2015) for a critical review of the literature on neopatrimonialism.

${ }^{10}$ See also Hopkins (1987). 
circles. Dolan and Rajak $(2016,515)$ highlight a shift in framings of African entrepreneurialism, whereby 'it was cast as innate, needing only to be unleashed, to an emphasis on training, disciplining and transformation, driven as much from without and within'. This shift is significant, since it provides a platform for donors, business schools and other private actors to impart training for budding entrepreneurs to work their way towards eradicating poverty in their countries. ${ }^{11}$

Policy and academic discussions have also tended to focus on encouraging the growth of 'small enterprises' or 'small-and-medium enterprises' (SMEs). This, Mkandawire (1999) argues, is part of a Manichean discourse in which 'small is beautiful' and big is ugly. Successful development strategies focusing on the development of DBGs (as in East Asia) highlight that the role small-and-medium enterprises play depends on their relationships with larger enterprises. National Private Sector Development Strategies in most African countries tend to focus their attention on encouraging more businesses to operate or be registered in a country, similar to the World Bank's Doing Business Index. ${ }^{12}$ This fails to acknowledge the demand side of the economy. This is a considerable oversight, since many of the largest African DBGs have grown through responding to domestic and regional demand within their country. Rwanda has studiously made concerted efforts to rise up the World Bank's Doing Business Index (DBI) (Behuria, 2018b). By meeting the DBl's requirements, the government has concentrated efforts on reducing red tape and making it easy to register a company. However, very few new companies survive beyond three years. ${ }^{13}$ Rather than responding to the needs of domestic and regional markets, governments (like Rwanda's) have been prompted by global indexes (like the $\mathrm{DBI}$ ) to concentrate their efforts on regulating companies in a uniform way, rather than responding to the needs of their economies.

The influence of the GVC/GPNs literature has contributed to the prioritisation of partnering with global lead firms (Gereffi et al., 2005; Henderson et al., 2002; Gereffi, 2014) in most countries where industrial policies are being implemented. The place for domestic firms in GVC/GPN-oriented industrial policy is to absorb the technology from foreign firms. Within such literature, the state is not perceived as being capable of picking winners (Kaplinsky and Morris, 2016). GVC/GPN studies have long been criticised for neglecting the state's role in economic upgrading and issues of domestic political economy (Cramer, 1999: Neilson, 2014). ${ }^{14}$ Thus, while structural adjustment and neopatrimonialism-based explanations of African development criticised close state-business relations in African countries, the GVC/GPN literature partially

\footnotetext{
${ }^{11}$ Fick's $(2002,2006)$ books on African entrepreneurialism exemplify this shift, where training in American universities is perceived to be of significant benefit before they return to start businesses in their home countries.

${ }_{12}$ See Hallward-Driemeier and Pritchett (2015) for a critique of the World Bank's Doing Business Index.

${ }^{13}$ Interviews, Rwanda Private Sector Federation (PSF), May 2013 and January 2015; annual reports.

${ }^{14} \mathrm{~A}$ new strand of the GVC/GPN literature explicitly focuses on the state's role in GVC/GPNs (Smith, 2015; Horner, 2017; Mayer and Phillips, 2017; Alford and Phillips, 2018; Behuria, 2018c).
} 
contributed to refocusing government attention on developing relationships with foreign lead firms, rather than focusing on how governments could integrate domestic firms in industrialisation strategies. This was a sharp departure from the linkagebased development strategies advocated by early development economists like Albert Hirschman (1977).

A broader concern is that mainstream neoclassical and public choice assumptions, closely associated with neopatrimonialsm-based arguments, have dominated the ways in which African politics and development have been constructed in the imaginaries of social science scholars. Another alternative paradigm - the dependency school - has long been criticised for retaining assumptions that a programme for African development 'cannot succeed in generating independent industrialization' through a Western-dominated economic system (Kennedy, 1994, 193). Though the study of African capitalists has been discouraged by such assumptions, the capitalists themselves have grown and diversified their activities across the continent. The next section describes the state of research on African capitalists.

\subsection{African capitalists: The state of research}

The social sciences literature on capitalist classes - particularly work on Latin America - stressed the influence that specific historical circumstances had on the development of internal capitalist classes in each country (O' Donnell, 1979; Cardoso and Faletto, 1967). Similarly, varied histories of colonialism and different postindependence trajectories have influenced the diversity of experiences among African capitalist classes. Leys (1982) argues that in some African countries (Kenya and the Ivory Coast), the bourgeoisies that had emerged in the post-war years were assisted by white settler enclaves, which prioritised internally oriented development, including encouraging the creation of a wage-labour force under colonialism. In comparison, though there may have been signs of emerging capitalists in Ghana in the 1960s, Nkrumah's attitude towards the private sector obstructed their growth (Kennedy, 1988). Whitfield (2018) argues that the weakness of the domestic capitalist class (along with a competitive clientelist political settlement) continues to obstruct transformation in Ghana. Among pre-independence governments, Nkrumah was not alone in retaining a distance from domestic private capitalists. For leaders of newly independent African countries, the position of domestic capitalists became central to the political calculus of their rule (Iliffe, 1983; Boone, 1992). However, the capacity to control independent domestic capitalists varied across countries.

The initial study of Africa's capitalist classes focused on examining the status of domestic capitalists vis-à-vis the state and foreign capital. Most scholars were primarily interested in examining whether African capitalists acted as a class and whether they were capable of leading their countries through processes of capitalist transformation. However, since then, the study of capitalists as a 'class' has been overshadowed by the study of 'business associations' or on sectoral studies that ignore the wider status of capitalist classes in domestic political economies. This 
paper proposes to study the politics of capitalist classes through a specific focus on DBGs. Since DBGs are diversified, their interests are more closely aligned with the broader health of their host economies, rather than narrow sectoral interests. Though they compete with one another, their diversification means they are often likely to have common interests in their dialogues with government. In most African countries, business associations do not have as much influence as is often presumed and individual DBGs rarely rely on associations as their primary route through which their complaints are communicated. ${ }^{15}$

The tendency towards apolitical study of business-state relations is most evident in the focus on business associations. Both quantitative and qualitative literature have focused on analysing effective state-business relations in Africa through an analysis of public-private dialogue or the strength of business associations (Brautigam et al., 2002; Sen and Te Velde, 2009; Qureshi and Te Velde, 2013). However, the effectiveness of business associations is highly context-specific, as Doner and Schneider (2000) show in their review of the literature of business associations. There are reasons why business associations are important and were chosen as a proxy for effectiveness. In studies, evolving out of the developmental state literature, productive associations tend to exhibit high member density, effective internal interest mediation and the provision of valuable resources to their members (Doner and Schneider, 2000; Weiss, 1998). There is variation between and within African countries in the performance of business associations. This is particularly evident since, in the last two decades, within countries, several competing business associations have emerged with conflicting and overlapping agendas. Donor funding, often managed directly by the government or captured by certain individuals, has driven this expansion. Often, a familiar story plays out, with the business association disappearing once donor funding runs out.

Studying business associations as a proxy for the strength of African capitalist classes distracts from the aim of studying African capitalists and the political economies in which they operate. The study of DBGs provides an opportunity to directly examine how politics influences the growth, functions and diversification strategies of domestic firms. Some progress has been made in developing a database of domestic firms in specific African countries. The International Growth Centre has published enterprise maps, which provide business histories about several firms in Zambia, Ethiopia, Ghana, Rwanda, Tanzania and Mozambique (Sutton and Kellow, 2010; Sutton and Kpentey, 2012; Sutton and Olomi, 2012; Sutton, 2014; Sutton and Langmead, 2014; Gathani and Stoelinga, 2013). Though these studies will form a basis for the future examination of business-state relations in the countries in which fieldwork was conducted, they remain quiet on how politics impacted the growth of firms. Focus on how politics has affected the growth of particular businesses has been restricted to the study of political and military investment groups, as in the case of Rwanda and Ethiopia (Booth and Golooba-

\footnotetext{
${ }^{15}$ Interviews, Rwandan, Kenyan, Tanzanian, Ethiopian and Uganda businesspeople, October 2011-September 2018.
} 
Mutebi, 2012; Behuria, 2015, 2016, 2018a; Vaughan and Gebremichael, 2011) or of large firms such as Angola's SONANGOL (Soares de Oliveira, 2007). Attempts have also been made to develop typologies of how state-aligned firms have developed in dominant political environments (Abegaz, 2013; Weis, 2014).

With the marginalisation of the study of African capitalists and capitalist classes from academic literature, political risk firms and economic journalism have taken up the mantle of developing databases and lists of Africa's richest citizens and firms and publishing positive stories about the potential of indigenous firms to contribute to African development (BCG, 2010; McKinsey, 2010, 2014; Mcnamee et al., 2015; Nsehe, 2018). Despite the limited data available, Forbes reporters regularly publish reports on the business activities of the continent's richest individuals and their firms and have also maintained lists on specific countries. The Africa Report has also maintained lists of the 500 most profitable African companies across the continent and compiles similar 'most profitable' lists in specific sectors, including banking. The data is sparse and subject to methodological limitations, as is the case with most data related to African economies (Jerven, 2013).

The challenge of identifying the largest firms is made all the more difficult because the financial reporting requirements on domestic companies vary by country. Globally, Businessweek's Global 1200 Index and the Fortune Global 500 may be able to have closer approximations of the resources of firms, because multinational companies may have to report financial statements to their shareholders. Yet, even indexes like the Dow Jones Africa Titans Index only include details of the companies listed on stock exchanges, which are either absent or underdeveloped in most African countries. There are limited incentives for domestic companies in most African countries to be transparent with their accounts. Given that most African countries have liberalised their capital accounts and financial sectors (Stein, 2010), it is much easier to ensure finances are movable, thus leaving countries more susceptible to capital flight.

The next section engages with existing literature on business-state relations to introduce a typology of African DBGs. Though there is a paucity of data available, this paper calls for context-specific studies of African political economies to analyse how a variety of DBGs have emerged within countries and across the continent.

\subsection{Typology of African DBGs}

DBGs are the predominant form of organisation of the largest domestic firms across the world (Khanna and Yafeh, 2007; Schneider, 2009). ${ }^{16}$ Though they dominate the private sector in most countries, they remain understudied (Haggard et al., 1996; Schneider, 2009). One possible reason for this neglect is that the study of diversified

\footnotetext{
${ }^{16}$ DBGs are defined as 'a set of legally distinct firms that operate in three or more unrelated business activities and that are subject to centrlaised control, usually through significant equity holdings or other financial connections' (Schneider, 2009, 180-181). See Khanna and Yafeh (2007) for a review of the business groups literature.
} 
business groups fell from grace in the United States (US) in the 1980s. In the US, dominant managerial theories advocated the importance of corporate focus and warned of the disadvantages of unrelated diversification, arguing against the utility of DBGs (Montgomery, 1994; Martin and Sayrak, 2003). DBGs in developing countries tend to dominate large shares of the economies that host them and are more diversified in comparison to advanced industrial countries when they were at similar levels of development (Leff, 1978; Amsden and Hikino, 1994). In East Asia, DBGs were among the core institutions leading economic transformation. They provide a mechanism for capital mobility between activities, function like a capital market and are likely to perceive national growth to be more of a priority than narrow sectoral success (Leff, 1978; Schneider, 1998). Their diverse interests across sectors make them more likely to be concerned with the economy as a whole, rather than narrow sectoral interests (Olson, 1982). Since the health of DBGs largely follows the health of the economy that hosts them, DBGs are appropriate actors to consider when examining how domestic capital can be funnelled towards national industrialisation and broader development strategies.

Similar to most other developing countries, DBGs continue to be the predominant form of organisation for large firms in most African countries. Of course, there are also large companies, which concentrate their activities - usually found in services sectors and mining. Many African DBGs tend to be family-owned, as is true for a large share of DBGs around the world (which are often founded through family ownership) (Fisman and Khanna, 2004). Some are also directly owned by political families (as with the Kenyatta Family Businesses or Malawi's Press Corporation, owned by Hastings Banda's family). ${ }^{17}$ However, not all African DBGs are family businesses. There are exceptions, which include state-owned, state-affiliated groups or bank-centred groups.

This paper develops a fluid categorisation of DBGs, which is based on Schneider's (2009) categorisation of business groups. Schneider identified three categories of business groups on the basis of how their diversification and growth occurred: organic groups, policy-induced groups and portfolio groups. Schneider (2009) was largely concerned with private DBGs and did not differentiate on the basis of ownership. This paper adds the dimension of ownership to Schneider's (2009) framework, to examine why who owned DBGs mattered in relation to their future diversification. Figure 1 below illustrates how private, state-owned and party-affiliated DBGs vary in their diversification pathways (organic, policy-induced and portfolio). The diagram also emphasises that politics remains an explanatory factor in the growth and diversification of all DBGs, including privately-owned DBGs. In some cases, private DBGs form and diversify directly as a result of government support.

\footnotetext{
${ }^{17}$ Van Donge (2002) describes Banda's Press Corporation as Africa's chaebol. There are also other examples of DBGs, owned by political families. See Taylor (2012) for a discussion of Former Malawian President Bakili Muluzi's business interests. The relatives of several serving and former presidents also own DBGs. For example, Leo Mugabe (son of former Zimbabwean President Robert Mugabe) and Zacky Nujoma (the son of former Namibian President Sam Nujoma) (Taylor, 2012).
} 
Even DBGs, which grow more independently, remain dependent on government policy, procurement and other forms of support for future diversification. In fact, the cases show that DBGs rarely sustain their growth without political support, though they may begin activities on their own. Thus, the paper categorises companies into diversification pathways based on how they emerged, but recognises that their activities eventually transformed both because of political and economic opportunities.

Figure 1: An illustration of the variety of DBGs in African countries

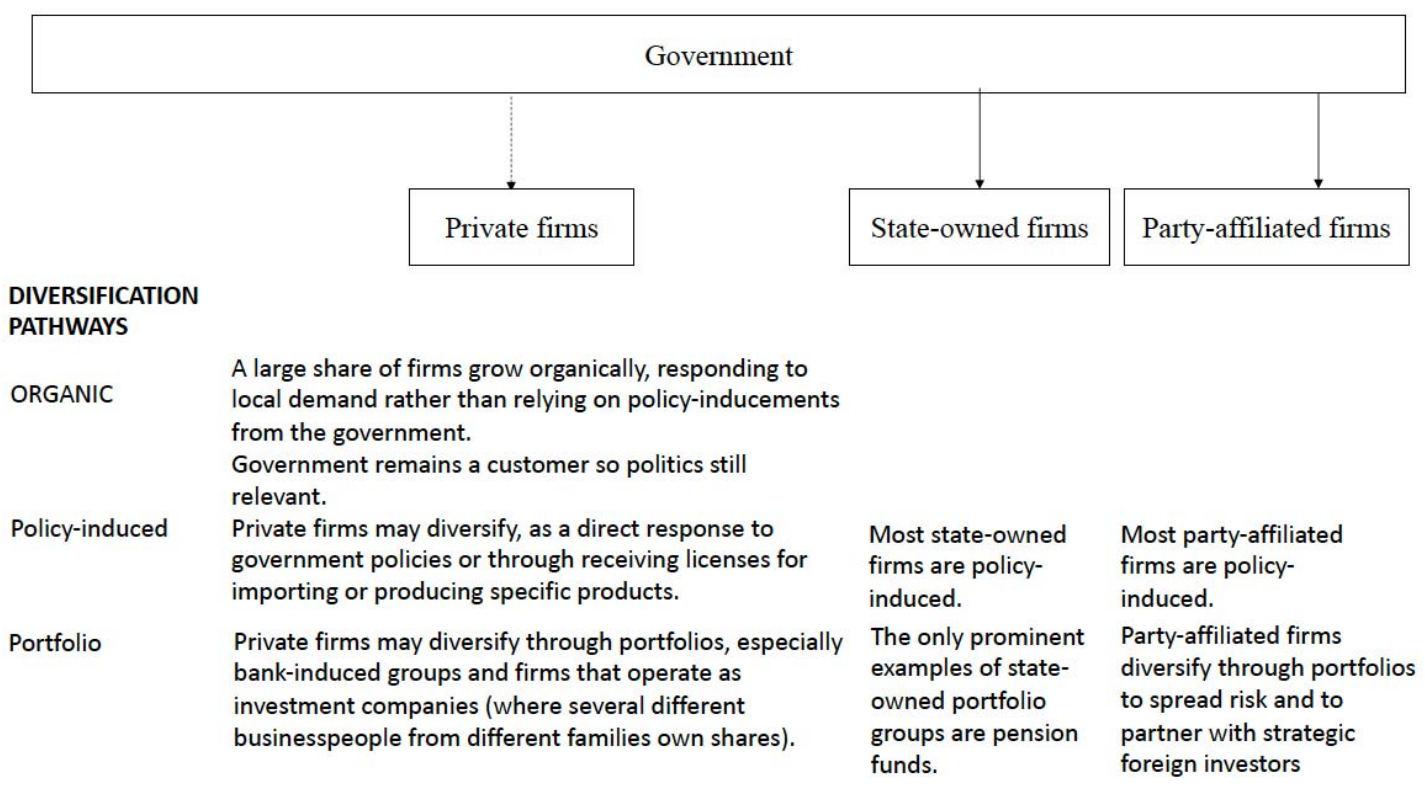

The categories for diversification pathways, highlighted in Schneider (2009), often overlap for specific countries. Over time, DBGs may diversify through a variety of pathways. The same group may have developed organically, but also take advantage of certain policy measures by the government and may also operate some portfolio investments through co-investing with other private enterprises, the government or foreign firms. Thus, assuming that DBGs operate restrictively within a category would not be helpful. Instead, it is useful to examine how politics may influence the preferred operations of particular DBGs and why diversification choices may occur through particular pathways. For example, Mann (2013) discusses how Sudan's organic DBG, DAL Group, succeeded through focusing on producing and diversifying within the consumer goods sector, rather than relying on state concessions, which was a very different strategy from Sudan's policy-induced and politically-connected High Tech Group.

\subsection{The fluid categories of African DBGs}

To understand how DBGs have grown over time, and how they have often been shaped by the governments in their host countries, a fluid categorisation approach (as emphasised here) can help understand the varied trajectories of African DBGs across the continent and how their growth strategies have been shaped by varied 
political environments. However, firms are initially categorised on the basis of their initial investments. The three diversification pathways are discussed below.

Organic groups are examples of DBGs that develop according to the logics of economies of scale and vertical integration. Thus, subsidiary companies are likely to have strong synergies in organisation, personnel and expertise. New investments are likely to be 'greenfield', while acquisitions would be 'horizontal', rather than linkagebased. Organic groups may have grown independently of government or may have much clearer links with politicians. But for any organic group, dependence on government in some form is inevitable in most African countries, since the government remains the most significant customer for firms. Public procurement $-\mathrm{a}$ relatively understudied area of research - is vital in the growth of any domestic business, thus the government is never far from determining the growth trajectories of business groups (Weiss, 2005).

Policy-induced groups are companies that diversify in response to government incentives or directives. Thus, the degree of political connections may be relatively higher than in organic groups. Examples of such groups have been cited in the literature on political connections between businesses and politicians (Faccio, 2006). Business groups during President Suharto's rule in Indonesia are perhaps most representative of the literature on political connections (Fisman, 2001). The Dangote Group is an example of an African firm that grew through policy-induced diversification to productive sectors (cement). Akinyoade and Uche (2018) illustrate how Dangote's relationship with former Nigerian President Obasanjo assisted in the enactment of Nigeria's Backward Integration Policy (BIP), which provided the foundation for Dangote Cement's expansions domestically and globally. The line between 'policy-induced' and 'organic' DBGs is a small one and difficult to distinguish. Though some groups - like the Dangote Group - may have enjoyed success due to political support, they grew relatively organically after initial support.

Portfolio groups are companies that are primarily concerned with managing risk and maximising returns in the market by buying and selling firms. Portfolio groups are more likely to concentrate their attention on buying firms and do less work in terms of establishing greenfield companies. Many of these companies are bank-centred groups and rely on investments in services sectors. Because their formation is often a result of different individuals or groups pooling resources together, or since they grow out of the financial sector, they are less likely to be family-owned. Examples include Kenyan groups, such as Centum and Transcentury. While some of these groups may list on stock exchanges to increase their access to capital and diversify their shareholding, others may consolidate their resources in response to limited capital markets as, for example, state-affiliated groups like Rwanda Investment Group (RIG) in Rwanda.

Though Schneider's (2009) categorisation does not deal with ownership directly, this paper tackles the question of who owns DBGs to help highlight how the politics of state-business relations has influenced the direction and strategies of DBG growth. 
Three categories are highlighted: state-owned groups are companies that are majority-owned by the governments and state-affiliated groups include party-owned and military-owned companies. Party-affiliated groups are the most prominent domestic firms in Africa's emerging developmental states - Rwanda and Ethiopia. However, state involvement in the economy is far from restricted to countries where centralised authority reigns and party-owned business groups are prominent throughout the continent. The third groups are private groups - which are the primary focus of Schneider's (2009) analysis - and tend to adopt diverse diversification strategies (organic, portfolio and policy-induced) compared to state-owned and partyaffiliated groups. Most DBG representatives mentioned that motivations for diversification are a delicate balance of opportunity and survival, which reflect what most companies perceive to be volatile business environments. ${ }^{18}$ However, another significant motivation for diversification - especially for family-owned firms - is to create employment for family members or simply 'to give our kids something to do'. ${ }^{19}$

The next section illustrates the emergence of varieties of different business groups through exploring the evolution of businesses in Rwanda, Kenya and Tanzania.

\subsection{Varieties of African capitalists: An overview of the emergence of firms in different contexts ${ }^{20}$}

\subsection{A comparison of difference in African DBGs}

There is considerable variation in how capitalist classes have evolved across the continent since the 1960s. Our understanding of the composition of capitalist classes and how domestic political economies have shaped their histories is best enhanced by context-specific analyses of particular countries. Thus, this section details three contrasting cases - Rwanda, Kenya and Tanzania - where countries differ in terms of the prominence of non-indigenous groups, the impact of civil war and the nature of domestic politics (whether in dominant authoritarian countries like Rwanda, one-party states like Tanzania or contested competitive politics in Kenya).

The positions of capitalist firms in all three countries have depended to some extent on the identity of those who own the firms. African politics is often contested on the basis of ethnic differentiation and there is a tendency within scholarship to avoid digging deeper than ethnic groupings. Clearly, firms receive support on the basis of personal networks, which are often rooted in ethnicity. However, some firms belonging to individuals from targeted ethnic groups survive (and even thrive) through retaining some political connections with ruling parties (or staying out of the way).

\footnotetext{
${ }^{18}$ Interviews, Kenyan, Ugandan, Tanzanian, Ethiopian and Rwandan DBGs, October 2011August 2018.

19 Interview, Kenyan DBG, February 2018. Similar comments made by Tanzanian, Ethiopian and Ugandan DBGs.

${ }^{20}$ A reference to Hall and Soskice (2001).
} 
Similarly, 'non-indigenous' groups - including European settlers, Asians, Lebanese or Greek traders - own some of the largest DBGs across the continent. Nonindigenous groups had roots in African societies in the pre-independence period. Butthere was variation in how independent African governments treated nonindigenous groups, who were seen to be non-native. In post-independent African countries, economic nationalism manifested as Africanisation, which was an attempt at increasing the indigenous presence in business and the economy. Several countries developed policies to achieve this: the Nigerianisation Decree of 1971, Zaireanisation in the 1970s, Uganda's seizure of Asian properties in 1972, Tanzania's Ujamaa after 1967, Ivoirite policies in Cote d'Ivoire and Zambianisation in 1968 via the Mulungushi reforms (Taylor, 2012). There were varying outcomes of such policies. For example, in Kenya, Africanisation displaced the Asian-Kenyan population from the trade sector, but many found other opportunities in manufacturing, finance, tourism and construction (Himbara, 1994). Despite their difficult position within domestic politics, many non-indigenous DBGs have retained a presence across the continent. Given that many non-indigenous DBGs have operated within the continent for over a century, this paper follows others (Himbara, 1994; Taylor, 2012) in viewing them alongside indigenous capital as 'African' or 'domestic' business.

Since independence, African capitalists have had to deal with three major shifts in the evolution of the domestic political economies in many African countries: independence, some attempt at nationalisation or indigenisation and, lastly, the privatisation (and liberalisation) that were part of structural adjustment programmes in the 1980s/1990s. Of course, in many countries, there have been changes in government and violence has fomented shifts in domestic political economies. This paper makes the case that the study of the emergence of African businesses should be conducted through context-specific historical political economy methods that make clear how politics has shaped the emergence of a variety of African firms. Existing studies of African capitalists are often divorced from the domestic political economies in which they operate. Where literature has focused on political economy, their analysis has been oriented within the confines of the assumptions associated with neopatrimonialism (Handley, 2008; Arriola, 2013).

Catalysing the emergence of a productive group of capitalists is a political process. Recognising the state's role in promoting (and also obstructing) the growth of market exchanges has long been emphasised by most scholarship within heterodox and neoclassical economics (Polanyi, 1944; Chang, 2002; Rodrik, 1997). But politics has been marginal to most studies of state-business relations in Africa, with few important exceptions (e.g. Whitfield et al., 2015; Gray, 2018).

\subsection{Rwanda: The evolution of business groups in a dominant setting}

Rwanda varies considerably from the other cases selected, as part of the comparison of DBGs conducted in this section. Firstly, all its post-independence governments (Gregoire Kayibanda, 1962-1973; Juvenal Habyarimana, 1973-1994; Rwandan 
Patriotic Front, 1994-current) have been authoritarian and have attempted to centralise control over the country, which has similarities with Rwandan monarchies in the pre-colonial era. Second, several rounds of large-scale violence shook the Rwandan economy in the 1960s, 1970s and 1990s. The 1994 genocide was a watermark in the history of the country and since then, the Rwandan Patriotic Front (RPF) has presided over a period of successful economic and social progress. None of the other countries selected for comparison has experienced similar large-scale violence. Third, though Asian Rwandans were prominent within the pre-1994 manufacturing sector and continue to operate today, they never acquired a similar economic status to the same groups in Tanzania and Kenya.

The first independent government (Kayibanda, 1962-1973) prioritised attracting foreign investment to manufacturing and agro-processing sectors, and most of the prominent domestic investments were through state-owned companies or Asian Rwandans. This continued into the second independent government, during which the domestic private sector comprised Asian Rwandans, businesspeople closely linked to the government, Tutsi business elites and state-owned enterprises.

After the 1994 genocide, the political economy of Rwanda's state-business relationships changed dramatically. Habyarimana's Hutu majoritarian government and his inner circle had relied on close relationships with businesspeople like Felicien Kabuga to lead activities in a variety of sectors (and, later, fund violence during the 1990s). Yet several prominent Tutsi businesspeople retained businesses in the country, with many having delicate relationships with the reigning Hutu government. The RPF inherited an economy in which a large share of the infrastructure was destroyed and rural populations (the majority of whom were Hutu) were wary of the new government (which was ethnically diverse on paper, but perceived to be Tutsiled). Several Tutsi businesspeople retained a prominent position in the economy until the 2000s (including many individuals who returned from neighbouring countries). Some, like Tribert Rujugiro and Faustin Mbundu - who had business interests in other countries prior to their return to Rwanda after 1994 - followed the government's lead in investing in strategic sectors. Rujugiro, in particular, became a central figure in Rwanda's private sector, retaining investments in a number of sectors and also holding government positions. Many prominent RPF-allied businesspeople eventually fell out with the government, including Rujugiro, whose assets - including real estate, tea factories and manufacturing firms - were seized a few years ago (Behuria, 2018a).

Major investments in reconstructing the country's economy were funded by donors and initiated by state-owned companies or the party-owned investment group, Crystal Ventures Limited (CVL). ${ }^{21}$ Military-owned investment groups - like the Horizon Group - continue to invest in strategic sectors for the country, as does government-owned (though military-managed) Ngali Industries. Private investment groups, which pool together resources among private businessmen (who are closely allied to the RPF), also operate in the country, with Rwanda Investment Group (RIG)

${ }^{21}$ CVL was initially named Tri-Star Investments. 
the most prominent example. The Rwanda Social Security Board (RSSB), though receiving comparatively less attention in the literature on Rwanda's state-affiliated DBGs, is the largest investor in the country. Others - owned by the government include Ngali (which is managed by the military) and Prime Holdings. All these DBGs have grown through political inducement, operating in sectors perceived to be necessary for transformation. Some (CVL, Horizon, RSSB and RIG) operate as portfolio companies - often investing with one another and otherwise partnering with foreign firms. The large incidence of state-affiliated DBGs is a response to the limited financial resources in the country and underdeveloped capital markets. This stands in contrast to Kenya's portfolio DBGs, many of which grew through listing on the country's stock exchange.

Thus, what some see as examples of the RPF's centralised rent accumulation and long-horizon orientation towards achieving development (Booth and Golooba-Mutebi, 2012), has manifested in a growing reliance on state-affiliated investment groups. This has led to a recurring story (Tangri, 1998; Mkandawire and Soludo, 1999) in postcolonial African governments, where the RPF's vulnerability and preference for centralising control over the economy has left limited space to support emerging individual capitalists. There are several instances of CVL and Horizon Group partnering to invest in certain firms (both with and without foreign investors). The Rwanda Social Security Board (RSSB) - a government-owned pension fund - is the biggest investor in the private sector and, according to domestic banks, holds about 60 percent of liquidity in the country. ${ }^{22}$ Most of the RSSB's investments are made in strategic investments for the country. Thus, in line with the government's longhorizon orientation, its large portfolio helps it to manage risks when investments fail.

The Rwandan example demonstrates how domestic politics has influenced the evolution of the country's private sector. In particular, state-affiliated DBGs dominate the domestic private sector. While businesspeople like Rujugiro (and the DBGs they owned) eventually disappeared, a few individual businesspeople have managed to retain some degree of diversification of their business interests. Table 1 describes four such groups, owned by RPF-allied businesspeople (Faustin Mbundu's MFK Group, Felicien Mutalikanwa's ProDev, Hatari Sekoko's Doyelcy and Egide Gatera's companies). All of these individuals are closely tied to the RPF (though Faustin Mbundu - a Ugandan-origin businessman - has also previously fallen out with senior RPF figures). Hatari Sekoko was a former military officer and Egide Gatera has a close relationship with the Kagame family. Mutalikanwa was an investor in MINIMEX (a maize processor), at a time when the government was prioritising maize production as part of its crop intensification programme. The growth of his business interests developed through securing a contract where the processed maize he owned was sold directly to the domestic Heineken subsidiary (Bralirwa). Since then, his investments have diversified to other agro-processing sectors - which are key government priority sectors.

\footnotetext{
${ }^{22}$ Interview, commercial bank, June 2017.
} 
The Rwandan government's centralised control over the economy has influenced the growth of a private sector, dominated by state-affiliated and policy-induced DBGs. Organic DBGs are not prominent within the economy. In comparison to Kenya and Tanzania, non-indigenous business families have not expanded their investments, though they retain control over their factories. Non-indigenous business families which operated before the genocide - have a frosty relationship with the RPF government, because they enjoyed support during Habyarimana's import substitution era. Many perceive their path to be blocked (though the government denies this) by state-affiliated groups or foreign investment.

Thus, the exploration of the growth of Rwandan DBGs suggests that Rwanda's political economy has enabled the emergence of diversified firms that are closely linked to the government. The RPF's ruling coalition has shaped the growth of a private sector, which is borne out of the anxiety it has towards individual domestic capitalists. In effect, the RPF's choice to organise the private sector primarily through party-affiliated DBGs is similar to Taiwan's strategy in the post-war years, when the state played the dominant role. However, the RPF is unlike Taiwan, in that the Rwandan government has been unable to attract strategic foreign investment with the attention of creating domestic linkages and supporting a transfer of technology between domestic SMEs. 


\begin{tabular}{|c|c|c|c|}
\hline \multicolumn{4}{|c|}{ Table 1: Varieties of DBGs in Rwanda } \\
\hline Name of DBG & Type & Description of Type & Sectors \\
\hline $\begin{array}{l}\text { Crystal Ventures Ltd. } \\
\text { (Formerly Tri-Start }\end{array}$ & $\begin{array}{l}\text { State-affiliated } \\
\text { (Policy-induced, later } \\
\text { portfolio) }\end{array}$ & $\begin{array}{l}\text { Party-owned DBG. } \\
\text { Often invests through } \\
\text { shareholdings in } \\
\text { subsidiaries, both in } \\
\text { partnership with other } \\
\text { state-affiliated DBGs } \\
\text { and foreign investors. }\end{array}$ & $\begin{array}{l}\text { Construction, } \\
\text { Construction } \\
\text { Materials, Agro- } \\
\text { processing, Real } \\
\text { Estate, Security }\end{array}$ \\
\hline Horizon Industries & $\begin{array}{l}\text { State-affiliated } \\
\text { (Policy-induced, later } \\
\text { Portfolio) }\end{array}$ & $\begin{array}{l}\text { Military-owned DBG. } \\
\text { Often invests through } \\
\text { shareholdings in } \\
\text { certain subsidiaries. }\end{array}$ & $\begin{array}{l}\text { Main investments in } \\
\text { Construction, } \\
\text { Logistics, Agro- } \\
\text { processing. }\end{array}$ \\
\hline Ngali Holdings Ltd. & $\begin{array}{l}\text { State-affiliated } \\
\text { (policy-induced) }\end{array}$ & $\begin{array}{l}\text { Government-owned } \\
\text { DBG (managed by } \\
\text { military). Invests in } \\
\text { strategic sectors. }\end{array}$ & $\begin{array}{l}\text { Energy, Information } \\
\text { and Communications } \\
\text { Technology, Mining, } \\
\text { Agro-processing, } \\
\text { Logistics. }\end{array}$ \\
\hline $\begin{array}{l}\text { Rwanda Investment } \\
\text { Group }\end{array}$ & $\begin{array}{l}\text { State-affiliated } \\
\text { (policy-induced, later } \\
\text { portfolio) }\end{array}$ & $\begin{array}{l}\text { Owned by RPF-allied } \\
\text { businesspeople. }\end{array}$ & $\begin{array}{l}\text { Energy, Construction } \\
\text { materials. }\end{array}$ \\
\hline $\begin{array}{l}\text { Rwanda Social } \\
\text { Security Board }\end{array}$ & $\begin{array}{l}\text { State-affiliated } \\
\text { (policy-induced, later } \\
\text { Portfolio) }\end{array}$ & $\begin{array}{l}\text { State-owned pension } \\
\text { fund; invests in } \\
\text { shareholdings of firms. }\end{array}$ & $\begin{array}{l}\text { Finance, Agro- } \\
\text { processing, } \\
\text { construction, Real } \\
\text { Estate, Insurance, } \\
\text { Tourism } \\
\end{array}$ \\
\hline Prime Holdings & $\begin{array}{l}\text { State-affiliated } \\
\text { (Policy-induced, later } \\
\text { portfolio) }\end{array}$ & $\begin{array}{l}\text { State-affiliated. } \\
\text { Invests in strategic } \\
\text { projects like Special } \\
\text { Economic Zone and } \\
\text { Kigali Convention } \\
\text { Centre. }\end{array}$ & Real Estate, Insurance. \\
\hline MFK Group & Policy-induced & $\begin{array}{l}\text { Owned by RPF-allied } \\
\text { businessman Faustin } \\
\text { Mbundu }\end{array}$ & $\begin{array}{l}\text { Coffee, Real Estate, } \\
\text { Tourism, Transport }\end{array}$ \\
\hline Pro-Dev Rwanda & Policy-induced. & $\begin{array}{l}\text { Grew out of maize } \\
\text { investments }\end{array}$ & Agro-processing \\
\hline Doyelcy Ltd. & $\begin{array}{l}\text { Policy-induced, later } \\
\text { portfolio }\end{array}$ & $\begin{array}{l}\text { Owned by RPF-allied } \\
\text { businessman Hatari } \\
\text { Sekoko }\end{array}$ & $\begin{array}{l}\text { Real Estate, } \\
\text { Construction }\end{array}$ \\
\hline $\begin{array}{l}\text { Egide Gatera's } \\
\text { companies }\end{array}$ & $\begin{array}{l}\text { Policy-induced, later } \\
\text { portfolio }\end{array}$ & $\begin{array}{l}\text { RPF-allied; } \\
\text { Diversification grew } \\
\text { out of privatisation }\end{array}$ & $\begin{array}{l}\text { Agro-processing, } \\
\text { Finance, Trading }\end{array}$ \\
\hline
\end{tabular}




\subsection{Kenya}

Kenya's political economy has been characterised by more competitive politics than the other cases mentioned here, with multiparty elections resulting in several changes in government. The Kenyan African National Union's (KANU) Jomo Kenyatta was president of the country from 1964 to 1978. Upon Kenyatta's death in 1978, KANU's Daniel Arap Moi became president and remained in the post till 2002. Mwai Kibaki's National Rainbow Coalition won the 2002 elections and Kibaki remained president till 2013. Uhuru Kenyatta's National Alliance Jubilee Party won the 2013 elections and has remained in power since then. During that time - despite an attempt at Africanisation - several examples of Asian-Kenyan organic and policyinduced DBGs have emerged as among the most prominent DBGs across the continent. Importantly though, indigenous Kenyan DBGs have also emerged. While many groups operate as portfolio DBGs (and some are bank-centred groups), political families also have large organic and policy-induced DBGs.

Within the study of Kenyan politics, there is a tendency to explain Kenyan politics through the lens of ethnicity (Berman, 1998; Lynch, 2006; Bedasso, 2015), with ethnic differences increasingly politicised over the last 30 years (Lynch, 2014). The study of Kenyan state-business relations is no different from the study of broader politics. It has largely been studied by scholars by distinguishing between the groups that different firms may originate from: Asian-Kenyan, Kikuyu or other ethnic groups. When generating broad categorisations of how Kenyan state-business relations were divided, distinguishing on the basis of ethnicity has been a useful instrument for scholars. However, if businesspeople belonged to the same ethnic group as the ruling president, they have not necessarily thrived. Similarly, not all businesspeople who belonged to 'targeted' ethnic groups like the Kikuyu group (during Moi's reign) experienced difficulties. The story of the emergence of Kenyan DBGs appears more complex than ethnicity-based explanations suggest.

The colonial period influenced the composition of Kenya's capitalist classes today. Both Asian-Kenyan and Kikuyu capitalists benefited from their positions during the colonial administration to become central to the accumulation drives of postindependent Kenyan governments. In the post-independent years, the Kenyatta government extended support to the emergent Kikuyu business elite. When Francis Macharia, a Kikuyu, became the first president of the Kenya National Chamber of Commerce and Industry ( $\mathrm{KNCCl})$, he sought better access to financing and licensing for indigenous entrepreneurs (primarily, Kikuyus) to combat the dominance of European settlers and Asian merchants (Swainson, 1980; Arriola, 2013). However, many Kikuyu businesses were targeted during Moi's reign (who was a Kalenjin). After Moi became president, he developed close relationships with the Asian business community and other indigenous businesspeople, supporting his co-ethnic Kalenjin groups to partner with international capital in domestic investments (Chege, 1998; Ajulu, 2002; Throup and Hornsby, 1998). Though many Kikuyu businesspeople - like Macharia - were targeted, others managed to reach political compromises with Moi and remained active (Arriola, 2013). Later, Arriola (2013) argues that Moi began to court Kikuyu entrepreneurs as he had lost control over regulating access to capital 
because of financial liberalisation. Importantly, Moi's support within the private sector went beyond Asian capitalists and also provided space for the accumulation of wealth among closely allied politicians and civil servants like Nicholas Biwott and Joshua Kulei.

The academic scholarship on Kenya's state-business relations in the 1990s disagreed about the extent of dominance of Asian-Kenyan capitalists within the private sector and the continuing relevance of Kikuyu ethnic groups (Himbara, 1994; Chege, 1998). Casting the debate through ethnic terms, rather than highlighting how different DBGs emerged and sustained themselves, contributes to neglecting the distinctions within groups (like Asian-Kenyans) and their relationships with governments.

A variety of Kenyan DBGs have emerged to dominate the domestic business landscape. Government policies, direct support and cronyism have shaped their emergence. Table 2 introduces a list of 10 Kenyan DBGs. These include DBGs owned by presidential families (Kenyatta, Moi), DBGs owned by former government officials (Sovereign Group, Biwott companies, Ndegwa family companies), a former government investment company that is now listed on the stock market (Centum), a portfolio DBG that was initially a savings company and grew into a portfolio DBG (Transcentury) and Asian-Kenyan DBGs that vary in their extent of direct relationships with politicians. Within Kenya, there are several other prominent DBGs - including the Aga Khan-owned IPS group, which operates as a portfolio DBG, largely investing in supporting companies operated within the Ismaili community. However, Table 2 lists 10 DBGs that showcase how politics has influenced the growth of different forms of DBGs operating within and beyond Kenya's economy.

Presidential family DBGs are a characteristic of Kenya's political-economic landscape, where prominent political families from across the political landscape all own diversified assets across the economy, making them among the wealthiest businesspeople in the country. The assets of these companies originate from when particular family members were in senior political positions in government. Thus, they are examples of policy-induced DBGs, but a large share of their investments has made them transform their operations to operate partially as portfolio DBGs. For example, though the Kenyatta family's initial investments may have been to consolidate control of certain firms, they have found it in their interest to either bring in a foreign investor (Danone's investments in Brookside Dairies) or through listing the company on the domestic stock exchange (for example, since listing the Commercial Bank of Africa (CBA) on the domestic stock exchange, the Kenyatta family still owns roughly 25 percent of the Bank).

Most other politician-owned business groups (examples include those owned by Nicholas Biwott, Joshua Kulei, Charles Njonjo and Philip Ndegwa) operate as 


\begin{tabular}{|c|c|c|c|}
\hline \multicolumn{4}{|c|}{ Table 2: Varieties of DBGs in Kenya } \\
\hline Name of DBG & Type & Description of Type & Sectors \\
\hline $\begin{array}{l}\text { Kenyatta Family } \\
\text { Companies }\end{array}$ & $\begin{array}{l}\text { Policy-induced (later } \\
\text { portfolio) }\end{array}$ & $\begin{array}{l}\text { Companies owned by } \\
\text { the Kenyatta Family }\end{array}$ & $\begin{array}{l}\text { Agribusiness, Finance, } \\
\text { Tourism, Education, } \\
\text { Media, Real Estate, } \\
\text { Timber, } \\
\text { Manufacturing, } \\
\text { Agricultural Land }\end{array}$ \\
\hline Moi Family Companies & Policy-induced & $\begin{array}{l}\text { Companies owned by } \\
\text { the Moi Family } \\
\text { (including Gideon Moi) }\end{array}$ & $\begin{array}{l}\text { Agribusiness, Finance, } \\
\text { Transport, Media, } \\
\text { Education, Agricultural } \\
\text { Land }\end{array}$ \\
\hline Sovereign Group & Policy-induced & $\begin{array}{l}\text { Companies owned by } \\
\text { Moi's former } \\
\text { secretary, Joshua Kulei }\end{array}$ & $\begin{array}{l}\text { Agribusiness, Tourism, } \\
\text { Media, Real Estate, } \\
\text { Security, Logistics, } \\
\text { Mining }\end{array}$ \\
\hline $\begin{array}{l}\text { Nicholas Biwott's } \\
\text { (now deceased) } \\
\text { companies }\end{array}$ & $\begin{array}{l}\text { Policy-induced and } \\
\text { portfolio }\end{array}$ & $\begin{array}{l}\text { Companies owned by } \\
\text { Former MP Biwott. } \\
\text { Current ownership } \\
\text { uncertain. }\end{array}$ & $\begin{array}{l}\text { Real Estate, } \\
\text { Agricultural Land, } \\
\text { Telecom, Finance, } \\
\text { Construction, Agro- } \\
\text { processing }\end{array}$ \\
\hline $\begin{array}{l}\text { Ndegwa family } \\
\text { businesses }\end{array}$ & $\begin{array}{l}\text { Policy-induced and } \\
\text { portfolio }\end{array}$ & $\begin{array}{l}\text { Companies owned by } \\
\text { former Central Bank } \\
\text { Governor, Philip } \\
\text { Ndegwa }\end{array}$ & $\begin{array}{l}\text { Finance, Insurance, } \\
\text { Real Estate, Agro- } \\
\text { processing, Transport, } \\
\text { Manufacturing } \\
\end{array}$ \\
\hline Centum Investments & $\begin{array}{l}\text { Policy-induced, later } \\
\text { portfolio }\end{array}$ & $\begin{array}{l}\text { Originally owned by } \\
\text { government. } \\
\text { Government retains } \\
\text { approximately } 20 \% \\
\text { shares; Leading } \\
\text { shareholder is Chris } \\
\text { Kirubi }\end{array}$ & $\begin{array}{l}\text { Agribusiness, ICT, } \\
\text { Finance, Real Estate, } \\
\text { Power, Healthcare, } \\
\text { Education, } \\
\text { Manufacturing }\end{array}$ \\
\hline Transcentury & Portfolio & $\begin{array}{l}\text { Company that was } \\
\text { established as a } \\
\text { savings association } \\
\text { and grew into a } \\
\text { portfolio company. }\end{array}$ & $\begin{array}{l}\text { Power, Infrastructure, } \\
\text { Engineering, Real } \\
\text { Estate }\end{array}$ \\
\hline Sameer Group & $\begin{array}{l}\text { Organic (some } \\
\text { portfolio) }\end{array}$ & $\begin{array}{l}\text { Owned by Naushad } \\
\text { Merali family. }\end{array}$ & $\begin{array}{l}\text { Agro-processing, Real } \\
\text { Estate, Manufacturing, } \\
\text { Finance }\end{array}$ \\
\hline Comcraft Group & $\begin{array}{l}\text { Organic (some } \\
\text { portfolio) }\end{array}$ & $\begin{array}{l}\text { Owned by Manu } \\
\text { Chandaria's family, } \\
\text { spanning investments } \\
\text { across several } \\
\text { countries. Also co- } \\
\text { owns Safal Group. }\end{array}$ & $\begin{array}{l}\text { Manufacturing, Real } \\
\text { Estate }\end{array}$ \\
\hline BIDCO & $\begin{array}{l}\text { Organic (some } \\
\text { portfolio) }\end{array}$ & $\begin{array}{l}\text { Owned by Vimal Shah } \\
\text { family. Spanning } \\
\text { investments across } \\
\text { the region. }\end{array}$ & $\begin{array}{l}\text { Agro-processing, Real } \\
\text { Estate, FMCG }\end{array}$ \\
\hline
\end{tabular}


portfolio DBGs, but were originally policy-induced. Chris Kirubi is an example of a businessman who has invested largely in developing portfolio DBGs in partnership with other domestic and global investors. He owns shares in Centum Investment Group, which is listed on the Nairobi and Kampala stock exchanges, Nation Media Investment Group and Kenya Commercial Bank. He also owns real estate (both in urban and rural areas) and Haco Industries (a household goods manufacturing company). Many of these DBGs experienced varying fortunes during different governments (Moi, Kibaki and Uhuru-Kenyatta). However, others have sustained themselves, showing that not all businesspeople were similarly affected by antiethnic sentiment, often highlighted when discussing how state-business relationships evolved during different presidential governments.

The status of Asian-Kenyan DBGs also varies considerably. Sameer Group - owned by Naushad Merali (closely allied to Moi) - maintained political connections during the Kibaki government and continued to position itself among the leading business groups in the country. Some DBGs developed more organically, with less direct reliance on political inducement than others. Some of these DBGs argue that relying less on government was 'because that was the only way our businesses could survive'. ${ }^{23}$ The Comcraft Group, owned by Manu Chandaria's family, is one example of an organic DBG. Chandaria was the founding Chairman of the East African Business Council and the Kenya Private Sector Alliance. Though the growth of his DBG has depended (to some degree) on government procurement, it has continued to grow across successive governments and has expanded across the continent and to Europe and Asia. ${ }^{24}$ Thus, it could be argued that large DBGs obtain enough structural power in the country so that specific governments eventually find it difficult to operate against their interests.

The diverse composition of Kenya's capitalist class is a product of the country's competitive political environment. Though ethnicity may have played a role in defining which groups were able to access opportunities, some individuals within particular ethnic groups have retained their status through successive governments. Ethnicity has also been significant for the development of collective investments to support industrialisation. For example, the country's prominent politicians and businesspeople established the Gikuyu, Embu, Meru Association (GEMA), which invested heavily in land, property and manufacturing projects. GEMA was disbanded after Moi banned ethnic associations (Arriola, 2013), but still continued to operate 'underground' as Agricultural and Industrial Holdings Ltd. (Widner, 1993).

In comparison to Rwanda, state-affiliated DBGs are less evident. Kenya's marketbased development strategy has contributed to the growth of varying forms of DBGs

\footnotetext{
${ }^{23}$ Interview, Kenyan DBG, February 2018.

${ }^{24}$ Manu Chandaria's assets are distinct from Chandaria Industries and Kenpoly (owned by Hanish Chandaria's family). These groups are all distinct from one another and the families are only distantly related. However, this is often confused in business journalism and academic publications, which often assume that since all these DBGs are owned by individuals who have the same name, they must be part of the same family.
} 
that have invested in both productive (manufacturing) and rentier (real estate, finance) sectors. Clearly, political connections have been important in supporting the emergence of DBGs and continue to be highlighted by examples of grand corruption (Mwangi, 2008). Yet political connections have not resulted in stagnation and have often been the basis for further diversification. Even within a contested political economy, where multiparty elections force a reconstitution of state-business relationships, the growth of some large businesses has meant that they have grown to an extent (and have diversified, with several investments abroad), making them less vulnerable to fractious domestic politics.

\subsection{Tanzania}

Tanzania's post-colonial history sets it apart from the other cases in this paper. The country's politics has been dominated by the ruling party, Chama Cha Mapinduzi (CCM), which is the continent's second-longest ruling party after South Africa's African National Congress. In 1961, Tanzania (then Tanganyika) became independent. ${ }^{25}$ From the 1960s onwards, Julius Nyerere - the country's first president) - aimed at further centralisation of power across the country, though his party dominated the first elections (Kelsall, 2013). The ruling party's relationship with the private sector has been turbulent over the years. Nationalisation in the 1970s saw several capitalist classes lose ownership of their farms and a large amount of their land, motivating many to leave the country. Subsequently, privatisation and liberalisation (after the implementation of structural adjustment programmes) have provided the foundation for the rapid growth of some DBGs over the last two to three decades.

In the early 1990s, many Asian-Tanzanians - who were close to the government and many of whom profited from currency speculation and debt purchases - bought state-owned entities that were put up for sale. Some Asian-Tanzanians and ArabTanzanians also made greenfield investments. The largest DBGs in Tanzania have grown within the last three decades (a much shorter timespan compared to Kenyan DBGs). Most operate as a combination of organic and policy-induced DBGs. Sutton and Olomi (2012) highlight five DBGs that they perceive to be the largest in the economy - METL, Azam, Sumaria, Motisun and Mac (Table 3). Except for Azam (owned by the Bakhresa family), the four other DBGs belong to Asian-Tanzanian families. Some of these groups - like Sumaria - were among the few private manufacturing companies operating in the country in the 1970s. Many DBGs currently in existence operated as traders during the nationalisation period, with their wealth heavily dependent on securing government licences for trading (Sutton and Olomi, 2012).

\footnotetext{
${ }^{25}$ Tanganyika became Tanzania in 1964 after a union with Zanizibar. At the time, Tanzania's Tanzania African National Union (TANU) was the mainland's ruling party. In 1977, it merged with Zanzibar's Afro-Shirazi party, to become CCM.
} 
Unlike in Kenya, Asian-Tanzanians dominate the private sector in Tanzania. However, Asian-Tanzanian DBGs all discussed the lack of coordination among them and the divisions among their communities. While many Asian-Tanzanian DBGs may have a similar origin in Gujarat, India, they differ in religion, caste and communities (Nagar, 1996). Though a Tanzanian-Asian Development Authority (TADA) exists, representatives highlighted the distinctions within the group and the competitiveness among group members. ${ }^{26}$ Despite the large amount of differentiation among 'Asian-Tanzanians', there are few studies of Tanzania's state-business relations that analyse the group beyond their ethnic origin, contributing to our lack of understanding of how these groups may differ from each other in their operations and activities.

Table 3 lists six examples of Asian-Tanzanian DBGs (METL, Sumaria, Motisun, Mac, Noble Azania and Aziz). While some groups grew organically, others have developed portfolio operations. Sumaria, for example, partners in most investments with an indigenous investor. Mac Group and Motisun have both invested in a number of sectors as shareholders with different partners. For DBGs that operated in trading and manufacturing before the liberalisation era, Asian-Tanzanian firms report a 'difficult and uncertain relationship with the government, where we always had to be on the good side of government, but never attract too much attention. ${ }^{27}$ Aziz Group owned by Rostam Aziz (formerly a prominent member of the CCM) - is largely operated as a portfolio DBG, with several prominent investments, including a large shareholder in Vodacom Tanzania. Many investors who operate portfolio DBGs have less historical standing as manufacturers or traders within Tanzania and have profited from strategic investments through business and political networks during the post-liberalisation era. ${ }^{28}$

During colonial rule, several Asian-Tanzanian businessmen prospered, with some already developing policy-induced DBGs. The Jivanji Group was one such example, with the group's sisal interests within Tanzania contributing to making the DBG responsible for a large share of global sisal production. However, after Nyerere's nationalisation policies, a large share of businesses either exited Tanzania or restricted their economic activities to trading. In the 1980s - as the Tanzanian government was forced to rapidly devalue its currency - many Asian-Tanzanians were able to make vast amounts of money through currency speculation. During this time, the government reacted against such activities by taking severe actions against alleged 'economic saboteurs'. While some 'economic saboteurs' were targeted,others - who retained close political connections with the government benefited from the privatisation and liberalisation policies under the new Ali Hassan Mwinyi government. ${ }^{29}$ Despite economic success over the past three decades, nearly all Asian-Tanzanian DBGs spoke of an 'uncertain business environment' in Tanzania. This reflected the histories of individual business owners, with many fleeing the

\footnotetext{
${ }^{26}$ Interview, TADA, August 2018.

27 Interview, Tanzanian DBG, August 2018.

${ }^{28}$ Interview, Tanzanian businessperson, August 2018.

${ }^{29}$ Interviews, Tanzanian DBGs, August-September 2018.
} 
country in the 1980s and some being imprisoned. ${ }^{30}$ Their diversification strategies have comprised diversifying across sectors and into neighbouring countries, taking advantage of the geographical position of Tanzanian ports to grow through creating domestic and regional value-chains.

The largest DBGs that operate in the country grew aggressively during the period of market liberalisation over the last three decades. DBGs have developed varied strategies. Most of the large DBGs existed prior to liberalisation, but benefited through the privatisation and liberalisation reforms. Different DBGs gambled in relation to the extent of their political involvement. Some business owners chose to increase their instrumental power by becoming part of the CCM (including Mo Dewji and Rostam Aziz). Others have attempted to steer clear of the limelight, but all DBGs have to provide funds for politicians during elections and this became a point of contention during the recent election in 2015.

Since the current President John Magufuli assumed power in 2015, there have been further moves towards the centralisation of rents. Magufuli has aimed to reorganise the financial sector and paid closer attention to tax collection, which had been ignored by the previous government. ${ }^{31}$ Observers argue that the military, and even state-owned enterprises, may take a more active role in domestic investments. Magufuli's new government has also distanced the new CCM from its political connections with businesspeople-turned-politicians, including the Dewji family and Rostam Aziz. Other Asian-Tanzanian businesspeople and relatives of some leading businesspeople (like Rostam Aziz's brother, Akram Aziz) spent time in prison. Though some DBGs interpreted his policies as 'anti-private sector', others saw them as 'cleaning up a system that was out of control'. ${ }^{32}$ While some see a recent shift in Magufuli's attitude as becoming more attuned to working with the private sector (Andreoni, 2017), the majority of DBGs interviewed saw no signs of any change. ${ }^{33}$ The most anxious - among those interviewed - likened Magufuli's current policies to creating the foundation for policies similar to nationalisation in the 1970s and 1980s. Though such anxieties may be far from translating to actual policies, there is clearly a rapid shift in the way in which accumulation is organised in the country and the growth of DBGs may be reconfigured by the centralisation of political power in Tanzania.

Among the most impressive examples of DBGs is Azam Group, owned by Said Salim Bakhresa's family. Initially, Asian-Tanzanian DBGs remember Bakhresa as selling ice cream across Dar-es-Salaam in the 1980s. But his expansion efforts into various manufacturing, transport, insurance, food and beverages and agribusiness sectors have been universally lauded (by those interviewed) as an 'example of the very best businesses in Tanzania, always investing in the best people and best equipment. ${ }^{, 34}$

\footnotetext{
${ }^{30}$ Interviews, owners of Tanzanian DBGs, August 2018.

${ }^{31}$ Interviews, Tanzanian DBGs, August-September 2018.

32 Interviews, Tanzanian DBGs, August-September 2018.

33 Interviews, Tanzanian DBGs, August-September 2018.

34 Interviews, Tanzanian DBGs, August-September 2018.
} 
Azam Group's initial emergence is organic. However, there is evidence of some clear political inducement along the way, with the company benefiting from the privatisation of Tanzania's National Milling Corporation. The company has also had to provide funds for political parties during elections (like other large businesses), but has been less directly involved in politics than Aziz Group or METL. ${ }^{35}$

Indigenous Tanzanians are much less prominent in their ownership of DBGs, with some businesspeople arguing that this was part of the CCM's historical aversion towards supporting (and even allowing) the growth of domestic private sector firms. There are exceptions, including Reginald Mengi, who has been a leading voice in the private sector since his success in manufacturing in the 1980s (initially through investments in a ballpoint pen assembly plant, followed by subsequent diversification in manufacturing). He also owns Bonite Bottlers, the sole bottler of Coca-Cola in Northern Tanzania and producer of Kilimanjaro drinking water. There are also some examples of indigenously owned portfolio DBGs, including Ali Mufuruki's Heritage Investments, which, similar to Asian-Tanzanian business groups, have profited from strategic investments in the post-liberalisation era.

A growing shift towards the dominance and centralisation of rents tends to motivate support for the growth of state-affiliated DBGs. Magufuli has implemented policies that encourage both state investment and military investment to promote growth in strategic sectors. The growing prominence of multinational corporations and stateaffiliated companies can often crowd out domestic private investment if domestic companies are supported through linkages to state or MNC investments. Tanzania's state-business relations continue to be affected by changes in domestic politics and the ways in which the socialist ideological underpinnings of the party can be used to legitimise changes in its domestic political economy.

Table 3 shows how different DBGs have emerged within a short period of 2-3 decades. Restrictively discussing Tanzania's state-business relations in the terms of ethnicity or race masks the diversity of trajectories of domestic DBGs. The growth of Azam Group, an Arab-Tanzanian DBG, benefited from both the support of AsianTanzanian businesspeople, partnerships with indigenous traders through coordinating supply chains across the country and support from government. The growth of Asian-Tanzanian businesspeople was also not simply down to a community 'helping each other', as even a Tanzanian journalist mentioned. Instead, some DBGs - like Sumaria - entered partnerships with local businesspeople, ahead of partnering with Asian-Tanzanians. ${ }^{36}$

The government's role in shaping the growth trajectories of DBGs has been vital in the post-liberalisation era, and during the Magufuli era, the ways in which economic rents are distributed has already altered considerably.

\footnotetext{
${ }^{35}$ Interview, former Azam Group employee, August 2018.

${ }^{36}$ Interview, Tanzanian journalist, August 2018.
} 


\begin{tabular}{|c|c|c|c|}
\hline \multicolumn{4}{|c|}{ Table 3: Varieties of DBGs in Tanzania } \\
\hline Name of DBG & Type & Description of Type & Sectors \\
\hline METL Group & Organic & $\begin{array}{l}\text { Asian-Tanzanian } \\
\text { (Dewji Family); } \\
\text { diversification began } \\
\text { through trading. }\end{array}$ & $\begin{array}{l}\text { Manufacturing, } \\
\text { Agribusiness, Food } \\
\text { and Beverages, } \\
\text { Infrastructure, } \\
\text { Insurance, Trading, } \\
\text { Transport }\end{array}$ \\
\hline $\begin{array}{l}\text { Azam Group } \\
\text { (Bakhresa) }\end{array}$ & Organic & $\begin{array}{l}\text { Arab-Tanzanian } \\
\text { (Bakhresa Family); } \\
\text { started in services } \\
\text { (restaurant) in the } \\
\text { mid-1970s. }\end{array}$ & $\begin{array}{l}\text { Agro-processing, Food } \\
\text { and Beverages, } \\
\text { Marine Transport, } \\
\text { Trading, Media, } \\
\text { Manufacturing, } \\
\text { Football Team }\end{array}$ \\
\hline Sumaria Group & $\begin{array}{l}\text { Organic, later } \\
\text { portfolio }\end{array}$ & $\begin{array}{l}\text { Asian-Tanzanian } \\
\text { (owned by Jayesh } \\
\text { Shah and family); } \\
\text { started in trading, } \\
\text { invested in } \\
\text { manufacturing in the } \\
1960 \text { s/1970s. }\end{array}$ & $\begin{array}{l}\text { FMCG, Manufacturing, } \\
\text { Finance, Insurance, } \\
\text { Real Estate }\end{array}$ \\
\hline Motisun Holdings & $\begin{array}{l}\text { Organic, later } \\
\text { portfolio }\end{array}$ & $\begin{array}{l}\text { Asian-Tanzanian } \\
\text { (owned by Subhash } \\
\text { Patel family); started } \\
\text { in trading and } \\
\text { diversified into } \\
\text { manufacturing in the } \\
1980 \text { s/1990s. }\end{array}$ & $\begin{array}{l}\text { Manufacturing, } \\
\text { Mining, Construction } \\
\text { Materials, Real Estate, } \\
\text { Food and Beverages, } \\
\text { Hotels }\end{array}$ \\
\hline Mac Group & $\begin{array}{l}\text { Organic, later } \\
\text { portfolio }\end{array}$ & $\begin{array}{l}\text { Asian-Tanzanian } \\
\text { (owned by Yogesh } \\
\text { Manek); started in } \\
\text { cashew exporting in } \\
\text { the 1920s and trading. }\end{array}$ & $\begin{array}{l}\text { Finance, Insurance, } \\
\text { Real Estate, Mining, } \\
\text { Tea, Manufacturing, } \\
\text { Construction }\end{array}$ \\
\hline IPP Group & Organic & $\begin{array}{l}\text { Owned by Reginald } \\
\text { Mengi. Former } \\
\text { executive of PWC. }\end{array}$ & $\begin{array}{l}\text { Media, Beverages, } \\
\text { FMCG, Mining, Real } \\
\text { Estate, Manufacturing }\end{array}$ \\
\hline Turkys Group & Organic & $\begin{array}{l}\text { Zanzibar-based; } \\
\text { started as tailoring } \\
\text { firm in } 1970 \text { s. }\end{array}$ & $\begin{array}{l}\text { Manufacturing, } \\
\text { Hospitals, } \\
\text { Construction } \\
\text { materials, Hotels, } \\
\text { Trading } \\
\end{array}$ \\
\hline Noble Azania Group & Organic & $\begin{array}{l}\text { Owned by Asian- } \\
\text { Tanzanian (Jeetu Patel } \\
\text { family) }\end{array}$ & $\begin{array}{l}\text { Agriculture, } \\
\text { Manufacturing, } \\
\text { Finance, Real Estate }\end{array}$ \\
\hline Aziz Group & Portfolio & $\begin{array}{l}\text { Owned by Asian- } \\
\text { Tanzanian (Rostam } \\
\text { Aziz Family) }\end{array}$ & $\begin{array}{l}\text { Telecom, Mining, } \\
\text { Tourism, } \\
\text { Manufacturing, Media }\end{array}$ \\
\hline $\begin{array}{l}\text { Infotech Investment } \\
\text { Group }\end{array}$ & Portfolio & $\begin{array}{l}\text { Owned by Ali } \\
\text { Mufuruki }\end{array}$ & $\begin{array}{l}\text { Retail, Telecom, } \\
\text { Energy, Media, Real } \\
\text { Estate }\end{array}$ \\
\hline
\end{tabular}




\subsection{A comparison of DBG growth: What's important?}

An analysis of the emergence of DBGs provides some interesting highlights. The salience of political connections between governments and businesses has been mentioned. However, it is also important to highlight how the strategic direction and authority of governments differed across the three countries, how the extent to which DBGs involved themselves in politics varied and how the distribution of power between ruling coalitions and DBGs differed in contributing to diversification pathways.

In a centralised political system like Rwanda, the government's strategic direction contributes to capitalist partners benefiting from investments in particular sectors. However, there is limited evidence that organic investments from the private sector would be similarly supported. The government retains more power than any independent domestic capitalist actor and has, in fact, acted against the growth of some independent businesses. Independent businesses have limited structural or instrumental power. In a competitive political system like Kenya, large DBGs have formed that have significant structural power. Successive governments, often dependent on such actors, work in line with the interests of well-developed business associations. In Tanzania, until recently, DBGs had begun to exert considerable power within the country, with previous governments 'letting large-scale tax evasion take place. ${ }^{37}$ With the new Magufuli government, increased emphasis on tax collection and monitoring business activity has shifted the distribution of power in the country towards the government, but placed the majority of the DBGs in a position of uncertainty, with many recounting the difficulties they experienced in the 1970s and 1980s. ${ }^{38}$

Across most African countries, services have been the fastest growing sectors (including finance, real estate, tourism). Timing matters in determining how DBGs evolve. Most newer DBGs tend to invest in services, and for countries following services-based strategies, like Rwanda, such growth would have been welcomed. However, for countries that aim to shift investment to manufacturing (like Tanzania and even Rwanda), there are challenges in shifting incentives towards industrial sectors. A clear government direction is necessary to urge DBGs to grow in particular directions, otherwise they are likely to diversify in sectors where their organisational capacities exist, in the fastest growing sectors, or (as often happens) through chance opportunities.

Across the three cases, the paper has also shown how DBGs have chosen to engage in politics to support the emergence of their businesses. While some businesses have directly supported family members who have become politicians, others have operated through less prominent deal-making, and a smaller minority stay out of the way. Inevitably, all large businesses have to fund political parties during elections and rely on the government to buy some of their products. The

\footnotetext{
${ }^{37}$ Interviews, DBGs, government officials, consultants, August 2018.

${ }^{38}$ Interviews, most Asian-Tanzanian DBGs, August 2018.
} 
extent of political engagement varies. The greater the political engagement, the more likely it may result in higher gains in the short term; but if there are shifts within the ruling coalition, it may threaten the growth of such companies (as some DBGs in Tanzania seem to suggest at the moment).

During the research, it became increasingly evident that, as DBGs grew over time, their activities increasingly developed into portfolio activities. This was particularly to hedge against risk, especially when engaging in diversification investments. Many DBGs did this in the absence of a stock market (although some DBGs operated purely through the stock market as portfolio DBGs). It was rare for DBGs - which originally operated in services sectors - to invest in industrial sectors, even as a portfolio investment. However, some DBGs - which originally operated in agriculture or manufacturing - would tend to diversify within agriculture or manufacturing. Thus, this suggests that DBGs often invests within similar sectors, though they may change their 'diversification pathway' category.

\subsection{Conclusion: The revival of industrial policy and the possibilities for African capitalists}

Industrial policy is resurfacing around the African continent, reminding some of the Pan-Africanist ideals associated with discussions of regional industrialisation in the 1960s and 1970s. Despite progress in discussions around the AfCFTA, there is some way to go before borders are opened and a continental consensus is built on how countries work together to develop a continental industrial policy. Such goals have an ideological appeal in their allusions to Pan-Africanist consensus-building and coordination. Yet the rhetoric of African governments operates in parallel to the 'Africapitalism' narratives, presented by some of Africa's wealthiest businesspeople, with statements steering clear of highlighting the important role that the state performed in supporting the growth of domestic businesses. This is partly down to the dominant market-let narratives that tend to dominate the public press in most African countries and global policy discourses. The revival of industrial policy discussions should, however, create a space to put state-business relationships centre stage, yet most academic and policy discourses have focused on how foreign firms can be enticed to invest in the industrialisation of African countries, rather than on how domestic capital can be integrated into those strategies. This showcases how the growth of African capital has generally operated quite distinctly from government and continent-wide policy and intellectual discussions.

This paper argues that the neglect of the study of African capitalists is an outcome of powerful intellectual trends within the African studies literature, with the 1990s' pessimistic assumptions about the nature of African capitalists continuing to dominate academic work today. The evidence in many African countries seems to contradict such pessimism. African DBGs have emerged - often with political support - and are contributing significantly to the growth of their home countries (and other countries in which they operate). This paper develops a fluid categorisation of African 
DBGs to help understand how politics has influenced the growth and diversification of domestic businesses across the continent.

The understanding of how politics has shaped the emergence of African DBGs has lagged behind our understanding of state-business literatures in East Asia, Latin America, South Asia and the West. Though deindustrialisation may have characterised the macro-level growth of most African countries (Rodrik, 2016), many DBGs have diversified, even concentrating their activities in manufacturing and agroprocessing sectors. Thus, DBGs operate in deindustrialised countries, often retaining some political authority, yet failing to become a central focus in national development strategies. The continuing relegation of domestic capital at the expense of foreign capital may be a result of domestic political difficulties, but is equally an outcome of pessimistic intellectual thought. 


\section{References}

Abegaz, B. (2013). 'Political parties in business: Rent seekers, developmentalists, or both?' Journal of Development Studies 49(11): 1467-1483.

Ajulu, R. (2002). 'Politicised ethnicity, competitive politics and conflict in Kenya: A historical perspective'. African Studies 61(2): 251-268.

Akinyoade, A. and Uche, C. (2018). 'Development built on crony capitalism? The Case of Dangote Cement'. Business History 60(6): 833-858.

Alford, M. and Phillips, N. (2018). 'The political economy of state governance in global production networks: Change, crisis and contestation in the South African fruit sector'. Review of International Political Economy 25(1): 98-121.

Amaeshi, K. and Idemudia, U. (2015). 'Africapitalism: A management idea for business in Africa?' Africa Journal of Management 1(2): 210-223.

Amsden, A. (1989). Asia's Next Giant: South Korea and Late Industrialization. New York: Oxford University Press.

Amsden, A. (2007). The Rise of "he rest": Challenges to the West from Lateindustrializing economies. Oxford: Oxford University Press.

Amsden, A. and Hikino, T. (1994). 'Project execution capability, organizational knowhow and conglomerate corporate growth in late industrialization'. Industrial and Corporate Change 3(1): 111-147.

Andreoni, A. (2017). 'Anti-corruption in Tanzania: A political settlements analysis'. Anti-Corruption Evidence Working Paper 1. London: SOAS.

Arriola, L. (2013). Multiethnic Coalitions in Africa: Business Financing of Opposition Election Campaigns. Cambridge: Cambridge University Press.

Austen, R. (1987). African Economic History. Berkeley, CA: University of California Press.

Bedasso, B. (2015). 'Ethnicity, intra-elite differentiation and political stability in Kenya'. African Affairs 114(456): 361-381.

Behuria, P. (2015). 'Between party capitalism and market reforms - Understanding sector differences in Rwanda'. Journal of Modern African Studies 53(3): 415450.

Behuria, P. (2016). 'Centralising rents and dispersing power while pursuing development: Exploring the strategic uses of military firms in Rwanda'. Review of African Political Economy 43(150): 630-647.

Behuria, P. (2018a). 'Examining effectiveness and learning in Rwandan policymaking: The varied outcomes of learning from failure in productive sector policies'. Journal of International Development 30(6):1023-1043.

Behuria, P. (2018b). 'Learning from role models in Rwanda: Incoherent emulation in the construction of a neoliberal developmental state'. New Political Economy 23(4): 422-440.

Behuria, P. (2018c). 'The politics of upgrading in global value chains: The case of Rwanda's coffee sector'. ESID Working Paper No. 108. Manchester: Effective States and Inclusive Development Research Centre.

Behuria, P., Buur, L. and Gray, H. (2017). 'Studying political settlements in Africa'. African Affairs 116(464): 508-525. 
Berman, B. (1998). 'Ethnicity, patronage and the African state: The politics of uncivil nationalism'. African Affairs 97: 305-341.

Berman, B. and Leys, C. (eds.) (1994). African Capitalists in African Development. London: Macmillan.

Biersteker, T. (1987). 'Indigenization and the Nigerian bourgeoisie'. In P. Lubeck (ed.), The African Bourgeoisie. Boulder, CO: Lynne Rienner, 249-280.

Block, F. (1987). Revising State Theory: Essays in Politics and Postindustrialism. Philadelphia, PA: Temple University Press.

Boone, C. (1990). 'The making of a rentier class: Wealth accumulation and political control in Senegal'. The Journal of Development Studies 26(3): 425-449.

Boone, C. (1992). Merchant Capital and the Roots of State Power in Senegal, 19301985. Cambridge: Cambridge University Press.

Boone, C. (1994). 'States and ruling classes in Sub-Saharan Africa: The enduring contradictions of power'. In: J. Migdal, A. Kohli and V. Shue (eds.), State Power and Social Forces: Domination and Transformation in the Third World. Cambridge: Cambridge University Press.

Booth, D. and Golooba-Mutebi, F. (2012). 'Development patrimonialism? The case of Rwanda'. African Affairs 111 (444): 379-403.

Boston Consultancy Group (BCG) (2010). The African Challengers: Global Competitors Emerge from the Overlooked Continent. Boston, MA: Boston Consulting Group.

Boyce, J. and Ndikumana, L. (2001). 'Is Africa a net creditor? New estimates of capital flight from severely indebted Sub-Saharan African countries, 1970-96'. Journal of Development Studies 38(2): 27-56.

Bratton, M. and Van de Walle, N. (1994). 'Neopatrimonial regimes and political transitions in Africa'. World Politics 46(4): 453-489.

Brautigam, D., Rakner, L. and Taylor, S. (2002). 'Business associations and growth coalitions in Sub-Saharan Africa'. Journal of Modern African Studies 40(4): 519-547.

Cardoso, F. and Faletto, E. (1967). Dependency and Development in Latin America. New York: Monthly Review Press.

Chang, H.-J. (2002). 'Breaking the mould: An institutionalist political economy alternative to the neo-liberal theory of the market and the state'. Cambridge Journal of Economics 26(5): 539-559.

Chege, M. (1998). 'Introducing race as a variable into the political economy of Kenya debate: An incendiary idea'. African Affairs 97(387): 209-230.

Cheng, T.-J. (1993). 'Guarding the commanding heights: The state as banker in Taiwan'. In S. Haggard, C.-H. Lee and S. Maxfield (eds.), The Politics of Finance in Developing Countries. Ithaca, NY: Cornell University Press.

Clapham, C. (1985). Third World Politics: An Introduction. London: Croom Helm.

Cramer, C. (1999). 'Can Africa industrialize by processing primary commodities? The case of Mozambican cashew nuts'. World Development 27(7): 1247-1266.

Culpepper, P. (2011). Quiet Politics and Business Power: Corporate Control in Europe and Japan. Cambridge: Cambridge University Press. 
Dolan, C. and Rajak, D. (2016). 'Remaking Africa's informal economies: Youth, entrepreneurship and the promise of inclusion at the bottom of the pyramid'. The Journal of Development Studies 52(4): 514-529.

Doner, R. and Schneider, B. R. (2000). 'Business associations and economic development: Why some associations contribute more than others'. Business and Politics 2(3): 261-288.

Doner, R., Ritchie, B. and Slater, D. (2005). 'Systemic vulnerability and the origins of developmental states: Northeast and Southeast Asia in comparative perspective'. International Organization 59(2): 327-361.

Eisenstadt, S. (1966). Modernization: Protest and Change. Englewood Cliffs, NJ: Prentice-Hall.

Ewing, A. (1964). 'Industrialization and the UN Economic Commission for Africa'. The Journal of Modern African Studies 2(3): 351-363.

Evans, P. (1995). Embedded Autonomy: States and Industrial Transformation. Princeton, NJ: Princeton University Press.

Faccio, M. (2006). 'Politically connected firms'. American Economic Review 96(1): 369-386.

Fick, D. (2002). Etnrepreneurship in Africa: A Study of Successes. Westport, CT: Quorum Books.

Fick, D. (2006). Africa: A Continent of Economic Opportunity. Johannesburg: STE Publishers.

Fisman, R. (2001). 'Estimating the value of political connections'. American Economic Review 91(4): 1095-1102.

Fisman, R. and Khanna, T. (2004). 'Facilitating development: The role of business groups'. World Development 32(4): 609-628.

Forrest, T. (1987). 'State capital, capitalist development and class formation in Nigeria'. In P. Lubeck (ed.), The African Bourgeoisie: Capitalist Development in Nigeria, Kenya and the Ivory Coast. Boulder, CO: Lynne Rienner, 307-342.

Gathani, S. and Stoelinga, D. (2013). Understanding Rwanda's Agribusiness and Manufacturing Sectors. London: IGC.

Gereffi, G. (2014). 'Global value chains in a post-Washington Consensus world'. Review of International Political Economy 21(1): 9-37.

Gereffi, G., Humphrey, J. and Sturgeon, T. (2005). 'The governance of global value chains'. Review of International Political Economy 12(1): 78-104.

Gokgur, N. (2012). 'Rwanda's ruling party-owned enterprises: Do they enhance or impede development?' IOB Working Papers No. 2012-03. Antwerp: University of Antwerp.

Gray, H. (2018). Turbulence and Order in Economic Development: Institutions and Economic Transformation in Tanzania and Vietnam. Oxford: Oxford University Press.

Haggard, S., Maxfield, S. and Schneider, B. R.. (1996). 'Theories of business and business-state relations'. In S. Maxfield and B. R. Schneider (eds.) Business and the State in Developing Countries. Ithaca, NY: Cornell University Press, 36-62.

Hall, P. and Soskice, D. (eds.) (2001). Varieties of Capitalism: The Institutional Foundations of Comparative Advantage. Oxford: Oxford University Press. 
Hallward-Driemeier, M. and Pritchett, L. (2015). 'How business is done in the developing world: Deals versus rules'. Journal of Economic Perspectives 29(3): 121-140.

Handley, A. (2008). Business and the State in Africa: Economic Policy-making in the Neoliberal Era. Cambridge: Cambridge University Press.

Henderson, J., Dicken, P., Hess, M., Coe, N. and Yeung, H. (2002). 'Global production networks and the analysis of economic development'. Review of International Political Economy 9(3): 436-464.

Himbara, D. (1994). Kenyan Capitalists, the State, and Development. Nairobi: East African Educational Publishers.

Hirschman, A. O. (1977). 'A generalized linkage approach to development, with special reference to staples'. Economic Development and Cultural Change 25: 67-98.

Hopkins, A. (1987). 'Big business in African studies'. Journal of African History 28(1): 119-140.

Horner, R. (2017). 'Beyond facilitator? State roles in global value chains and global production networks'. Geography Compass 11(2): 1-13.

Iheduru, O. (2018). 'The African corporation, "Africapitalism" and regional integration in Africa'. In A. Nolke and C. May (eds.), Handbook of the International Political Economy of the Corporation. London: Edward Elgar, 329-348.

Iliffe, J. (1983). The Emergence of African Capitalism. London: Macmillan.

Iliffe, J. (2011). Obasanjo, Nigeria and the World. Woodbridge, UK: James Currey.

Jerven, M. (2013). Poor Numbers: How We Are Misled by African Development Statistics and What to Do about It. Ithaca, NY: Cornell University Press.

Kaplinsky, R. (1980). 'Capitalist accumulation in the periphery: The Kenyan case reexamined'. Review of African Political Economy 17: 85-105.

Kaplinsky, R. and Morris, M. (2016). 'Thinning and thickening: Productive sector policies in the era of global value chains'. European Journal of Development Research 28(4): 625-645.

Kasfir, N. (1987). 'Class, political domination and the African state'. In Z. Ergas (ed.), The African State in Transition. New York: St. Martin's, 45-61.

Kelsall, T. (2013). Business, Politics, and the State in Africa: Challenging the Orthodoxies on Growth and Transformation. London: Zed Books.

Kennedy, P. (1977). 'African businessmen and foreign capital: Collaboration or conflict?' African Affairs 76(303): 177-194.

Kennedy, P. (1988). African Capitalism: The Struggle for Ascendancy. Cambridge: Cambridge University Press.

Kennedy, P. (1994). 'Political barriers to African capitalism'. The Journal of Modern African Studies 32(2): 191-213.

Khanna, T. and Yafeh, Y. (2007). 'Business groups in emerging markets: Paragons or parasites?' Journal of Economic Literature 45(2): 331-372.

Kim, E. M. (1997). Big Business, Strong State: Collusion and Conflict in South Korean Development, 1960-1990. Albany, NY: State University of New York Press. 
Kitching, G. (1985). 'Politics, method and evidence in the Kenya debate'. In H. Bernstein and B. Campbell (eds.), Contradictions of Accumulation in Africa: Studies in Economy and State. Beverley Hills, CA: Sage, 115-151.

Lall, S. (2005). 'FDI, AGOA and manufactured exports by a landlocked, least developed African economy: Lesotho'. Journal of Development Studies 41(6): 998-1022.

Langdon, S. (1977). 'The state and capitalism in Kenya'. Review of African Political Economy 8: 90-98.

Leff, N. (1978). 'Industrial organisation and entrepreneurship in developing countries'. Economic Development and Cultural Change 26(4): 661-675.

Leys, C. (1975). Underdevelopment in Kenya: The Political Economy of Neocolonialism. Berkeley, CA: University of California Press.

Leys, C. (1978). 'Capital accumulation, class formation and dependency: The significance of the Kenyan case'. Socialist Register: 241-266.

Leys, C. (1982). 'African economic development in theory and practice. Daedalus 111(2): 99-124.

Leys, C. (1994). 'African capitalists and development: Theoretical questions'. In B. Berman and C. Leys (eds.), African Capitalists and African Development. Boulder, CO: Lynne Rienner, 11-38.

Lin, J. (ed.) (2012). New Structural Economics: A Framework for Rethinking Development and Policy. Washington, DC: World Bank.

Lin, J. (2018). 'China's rise and opportunity for structural transformation in Africa'. Journal of African Economies 27(1): i15-i28.

Lindblom, C. (1977). Politics and Markets: The World's Political-Economic Systems. New York: Basic Books.

Lubeck, P. (ed.) (1987). The African Bourgeoisie: Capitalist Development in Nigeria, Kenya and the Ivory Coast. Boulder, CO: Lynne Rienner.

Lynch, G. (2006). 'Negotiating ethnicity: Identity politics in contemporary Kenya'. Review of African Political Economy 33(107): 49-65.

Lynch, G. (2014). Electing the "alliance of the accused": The success of the Jubilee Alliance in Kenya's Rift Valley'. Journal of Eastern African Studies 8(1): 93114.

Mann, L. (2013). "We do our bit in our own space": DAL Group and the development of a curiously Sudanese enclave economy'. Journal of Modern African Studies 51(2): 279-303.

Martin, J. and Sayrak, A. (2003). 'Corporate diversification and shareholder value: A survey of recent evidence'. Journal of Corporate Finance 9: 37-57.

Mayer, F. and Phillips, N. (2017). 'Outsourcing governance: States and the politics of a "global value chain world"'. New Political Economy 22(2): 134-152.

Mckinsey (2010). Lions on the Move: Progress and Potential of African Economies. New York: Mckinsey Global Institute.

Mckinsey (2014). Lions Go Global: Deepening Africa's Ties to the United States. New York: Mckinsey Global Institute.

Mcnamee, T., Pearson, M. and Boer, W. (2015). Africans Investing in Africa: Understanding Business and Trade, Sector by Sector. New York: Palgrave Macmillan. 
McVey, R. (1992). Southeast Asian Capitalists. Ithaca, NY: Cornell Southeast Asia Program Publications.

Mkandawire, T. (1999). 'Developmental states and small enterprises. In K. King and S. Mcgrath (eds.), Enterprise in Africa - Between Poverty and Growth. Rugby, UK: Practical Action Publishing, 33-47.

Mkandawire, T. (2015). 'Neopatrimonialism and the political economy of economic performance in Africa: Critical reflections'. World Politics 67(3): 563-612.

Mkandawire, T. and Soludo, C. (1999). Our Continent, Our Future: African Perspectives on Structural Adjustment. Dakar: CODESRIA.

Montgomery, C. (1994). 'Corporate diversification'. Journal of Economic Perspectives 8: $163-178$.

Mwangi, O. (2008). 'Political corruption, party financing and democracy in Kenya'. Journal of Modern African Studies 46(2): 267-285.

Nagar, R. (1996). 'The South Asian diaspora in Tanzania: A history retold'. Comparative Studies of South Asia, Africa and the Middle East 16(2): 62-80.

Neilson, J. (2014). 'Value chains, neoliberalism and development practice: The Indonesian experience'. Review of International Political Economy 21(1): 3869.

Nsehe, M. (2018). 'The black billionaires 2018'. Forbes. 7 March.

O' Donnell, G. (1979). Modernization and Bureaucratic Authoritarianism: Studies in South American Politics. Berkeley, CA: University of California Press.

Olson, M. (1982). The Rise and Decline of Nations. New Haven, NJ: Yale University Press.

Oqubay, A. (2015). Made in Africa: Industrial Policy in Ethiopia. Oxford: Oxford University Press.

Ouma, S. (2019). 'Africapitalism: A critical commentary and assessment. In U. Idemudia and K. Amaeshi (eds.), Africapitalism: Sustainable Business and Development in Africa. London: Routledge.

Pitcher, A., Moran, M. and Johnston, M. (2009). 'Rethinking patrimonialism and neopatrimonialism in Africa'. African Studies Review 52(1): 125-156.

Polanyi, K. (1944). The Great Transformation. London: Beacon.

Prebisch, R. (1959). 'Commercial policy in the underdeveloped countries'. American Economic Review 49(2): 251-273.

Qureshi, M. and Te Velde, D. (2013). 'State-business relations, investment climate reform and firm productivity in Sub-Saharan Africa'. Journal of International Development 25(7): 912-935.

Rodrik, D. (1997). 'The "paradoxes" of a successful state'. European Economic Review 41(3-5): 411-442.

Rodrik, D. (2016). 'Premature deindustrialization'. Journal of Economic Growth 21(1): 1-33.

Sandbrook, R. (1986). 'The state and economic stagnation in tropical Africa'. World Development 14(3): 319-332.

Schneider, B. R. (1998). 'Review: Elusive synergy: Business-Ggovernment relations and development'. Comparative Politics 31(1): 101-122. 
Schneider, B. R. (2009). 'A comparative political economy of diversified business groups, or how states organize big business'. Review of International Political Economy 16(2): 178-201.

Sen, K. and Te Velde, D. (2009). 'State-business relations and economic growth in Sub-Saharan Africa'. The Journal of Development Studies 45(8); 1267-1283.

Shivji, I. (1976). Class Struggles in Tanzania. London: Monthly Review Press.

Smith, A. (2015). 'The state, institutional frameworks and the dynamics of capital in global production networks'. Progress in Human Geography 39(3): 290-315.

Soares de Oliveira, R. S. (2007). 'Business success, Angola style: Postcolonial politics and the rise and rise of Sonangol'. Journal of Modern African Studies 45(4): 595-619.

Stein, H. (2010). 'Financial liberalization, institutional transformation and credit allocation in developing countries: The World Bank and the internationalization of banking'. Cambridge Journal of Economics 34(2): 257273.

Sutton, J. (2014). An Enterprise Map of Mozambique. London: IGC.

Sutton, J. and Kellow, N. (2010). An Enterprise Map of Ethiopia. London: IGC.

Sutton, J. and Kpentey, B. (2012). An Enterprise Map of Ghana. London: IGC.

Sutton, J. and Olomi, D. (2012). An Enterprise Map of Tanzania. London: IGC.

Sutton, J. and Langmead, G. (2014). An Enterprise Map of Zambia. London: IGC.

Swainson, N. (1980). The Development of Corporate Capitalism in Kenya, 19181977. Berkeley, CA: University of California Press.

Tangri, R. (1998). 'Politics, capital and the state in Sub-Saharan Africa'. Commonwealth \& Comparative Politics 36(2): 108-122.

Taylor, S. (2012). Globalization and the Cultures of Business in Africa: From Patrimonialism to Profit. Bloomington, IN: Indiana University Press.

Throup, D. and Hornsby, C. (1998). Multi-Party Politics in Kenya: The Kenyatta and Moi States and the Triumph of the System in the 1992 Election. Oxford: James Currey.

United Nations (UN) (1963). Industrial Growth in Africa. New York: United Nations.

Van Donge, J. (2002). 'The fate of an African "chaebol": Malawi's Press Corporation after democratization'. Journal of Modern African Studies 40(4): 651-681.

Vaughan, S. and Gebremichael, M. (2011). 'Rethinking business and politics in Ethiopia: The role of EFFORT, the Endowment Fund for the Rehabilitation of Tigray'. African Politics and Power Programme Research Report 2. London: Overseas Development Institute.

Wade, R. (1990). Governing the Market: Economic Theory and the Role of Government in East Asian Industrialization. Princeton, NJ: Princeton University Press.

Weis, T. (2014). 'Dominant parties and the private sector in Sub-Saharan Africa: A typology of approaches'. Zeitschrift fur Vergleichende Politikwissenschaft 8(3/4): 263-281.

Weiss, L. (1998). The Myth of the Powerless State: Governing the Economy in a Global Era. London: Polity. 
Weiss, L. (2005). 'Global governance, national strategies: How industrialized strategies make room to move under the WTO'. Review of International Political Economy 12(5): 723-749.

Whitfield, L. (2018). Economies after Colonialism: Ghana and the Struggle for Power. Cambridge: Cambridge University Press.

Whitfield, L., Therkildsen, O., Buur, L. and Kjaer, A-.M. (2015). The Politics of African Industrial Policy: A Comparative Perspective. New York: Cambridge University Press.

Widner, J. (1993). The Rise of a Party-state in Kenya: From "Harambee!" to "Nyayo!"' Berkeley, CA: University of California Press.

Zolberg, A. (1966). Creating Political Order: The Party-states of West Africa. Chicago, IL: Rand McNally. 


\section{esid}

\section{The Effective States and Inclusive Development Research Centre}

The Effective States and Inclusive Development Research Centre (ESID) aims to improve the use of governance research evidence in decision-making. Our key focus is on the role of state effectiveness and elite commitment in achieving inclusive development and social justice.

ESID is a partnership of highly reputed research and policy institutes based in Africa, Asia, Europe and North America. The lead institution is the University of Manchester.

The other institutional partners are:

- $\quad$ BRAC Institute of Governance and Development, BRAC University, Dhaka

- $\quad$ Center for Democratic Development, Accra

- $\quad$ Center for International Development, Harvard University, Boston

- Department of Political and Administrative Studies, University of Malawi, Zomba

- $\quad$ Graduate School of Development, Policy \& Practice, Cape Town University

- Institute for Economic Growth, Delhi

In addition to its institutional partners, ESID has established a network of leading research collaborators and policy/uptake experts. 